\title{
Heavy metal pollutants and their spatial distribution in surface sediments from Thondi coast, Palk Bay, South India
}

\author{
Karthikeyan Perumal ${ }^{1 *}$, J Joseph Antony ${ }^{1}$ and Subagunasekar Muthuramalingam²
}

\begin{abstract}
Background: The concentration of heavy metals and their spatial distribution in surface sediments collected from the Thondi coast, Palk Bay, South India were analysed in this study. The sediment grain size, pH, EC, and major elements ( $\mathrm{Fe}$, and $\mathrm{Al})$, heavy metal concentrations ( $\mathrm{Mn}, \mathrm{Cr}, \mathrm{Zn}, \mathrm{Cd}, \mathrm{Ni}, \mathrm{Cu}$, and $\mathrm{Pb}$ ) were determined and the values for the geoaccumulation index $\left(I_{\text {geo }}\right)$, enrichment factor $(E F)$, potential contamination index $\left(C_{p}\right)$, potential ecological risk index (RI), contamination factor (CF), modified contamination degree $\left(m C_{d}\right)$, degree of contamination $\left(C_{d}\right)$, and potential contamination factors $\left(C_{p}\right)$ were calculated based on their background values to determine the pollution level of the study area. Multivariate analysis such as Pearson's correlation coefficient, principal component analysis/factor analysis (PCA/FA), cluster analysis, and regression analysis are a versatile method for identifying heavy metal sources and determining the relationship between pollutants in marine sediment.

Results: The pollution indices, namely $E F, C F, C_{d}, m C_{d}, C_{p}, R l$, and $I_{\text {geo, }}$ revealed that the heavy metal contamination was due to $\mathrm{Cd}$, while a moderate level of contamination was caused by $\mathrm{Cu}, \mathrm{Zn}$, $\mathrm{Pb}$, and $\mathrm{Cr}$. The principal component analysis and correlation matrix analysis showed a strong positive loading for $\mathrm{Cd}$ due to its high level of contamination in the study area. Anthropogenic inputs such as municipal wastewater, domestic sewage discharge, fishing harbour activities, and industrial and aquaculture wastes led to the increased $\mathrm{Cd}$ concentration in the study area. Moreover, the pollution load index revealed that the sediments were polluted by heavy metals.

Conclusion: The findings of this study revealed that the increased concentration of heavy metals in the study area increases the toxicity in the marine environment, thus affecting the ecosystem.
\end{abstract}

Keywords: Heavy metals, Toxicity, Pollution indices, Marine sediments

\section{Background}

The presence of toxic heavy metal pollutants in the aquatic ecosystem is mainly introduced through various natural and anthropogenic sources. Some of the main natural sources include the weathering processes (rocks and soils), atmospheric deposition of particles, and aeolian sediments. Anthropogenic sources, on the other

\footnotetext{
*Correspondence: pkarthikeyangold@gmail.com

${ }^{1}$ School of Marine Sciences, Department of Oceanography

and CoastalArea Studies, Alagappa University, Karaikudi, Tamil Nadu 630

003, India

Full list of author information is available at the end of the article
}

hand, include sewage waste dumping, mining activities, agricultural activities, discharge of industrial wastes into water bodies, and many other human activities that discard metal pollutants into the aquatic environment [1-4]. Anthropogenic sources have a high impact on the accumulation of heavy metal pollutants in the marine environment. The heavy metals are continuously accumulated in the rivers and deposited in the marine sediment as a sink. The major issues related with the persistence of heavy metals are toxicity, bioaccumulation, and biomagnification, which lead to indelible effects on the ecosystem, human health, and other living organisms [1, 5-9]. Therefore, it is essential to assess the distribution of these 
pollutants and their level of contamination to construe the mechanism of accumulation and transportation of these pollutants into the aquatic environment as well as obtain necessary information for the supervision, maintenance, and use of coastal areas.

In recent years, the increasing level of heavy metals detected in the sediment bed has become a major concern [10-13]. Several studies have revealed that marine sediments are highly polluted due to these heavy metals [14-16]. Therefore, the evaluation of heavy metal distribution in the surface sediments is useful for determining the pollution levels in the marine ecosystem of the southeast coast of India. In previous studies, many researchers focused on the heavy metal distribution and pollution status of the marine sediments (near the shore and shelf) in various regions along the Bay of Bengal in India [17-28]. This study, however, investigates the heavy metal pollution levels of the surface sediments along the Thondi coast, Bay of Bengal, South India. Therefore, it is essential to consider the key factors such as spatial distribution, sediment quality assessment, and concentration of heavy metal pollutants in the study area.

In this study, 24 surface sediment samples were collected around the coastal area of Thondi and analysed for sediment types and chemical composition. The main objectives of this study are to (1) measure the concentration of major elements ( $\mathrm{Fe}$, and $\mathrm{Al})$, heavy metals $(\mathrm{Mn}$, $\mathrm{Cr}, \mathrm{Zn}, \mathrm{Cu}, \mathrm{Cd}, \mathrm{Ni}$, and $\mathrm{Pb}$ ) in the study area; (2) assess the level of heavy metal contamination using enrichment factors $(\mathrm{EF})$, potential contamination index $\left(C_{\mathrm{p}}\right)$, geoaccumulation index $\left(I_{\text {geo }}\right)$, potential ecological risk index (PERI), contamination factor (CF), modified contamination degree $\left(\mathrm{mC}_{\mathrm{d}}\right)$, degree of contamination $\left(C_{\mathrm{d}}\right)$, and potential contamination factors $\left(C_{\mathrm{p}}\right)$; and (3) identify the relationship between the contaminants in the sediment and their possible sources in the study area using Pearson's correlation coefficient, principal component analysis/ factor analysis (PCA/FA), cluster analysis, and regression.

\section{Description of the study area}

Thondi lies within the latitude of $9^{\circ} 43^{\prime} 26^{\prime \prime} \mathrm{N}$ and longitude of $79^{\circ} 02^{\prime} 55^{\prime \prime} \mathrm{E}$ and is situated in the Palk Bay, Tamil Nadu, South India (Fig. 1a). The Palk Bay area is known for its rich marine biodiversity and resources such as seagrass, shrimps, seaweeds, lobsters, mollusks, coelenterates, holothurians, echinoderms, crabs, shellfishes, squids, and finfish. Seagrasses play a vital role in the production of commercially valuable fish in this region as it provides food and shelter for various marine organisms and is involved in the recycling of nutrients. The land use and land cover are classified as agriculture land (75\%), built-up land (5\%), wastelands (7\%), and water bodies
(13\%) in the study area (Fig. 1b). This region generally receives rainfall from the north-east and south-west monsoons. The shore water has an average depth of 1-2 $\mathrm{m}$ and the seawater is rich in nutrients with moderately high turbidity. The wave action along the Thondi coast is minimal and the sediments are muddy. Since the area serves as a treasure of various economically important marine resources, many socioeconomic and developmental activities such as agriculture, aquaculture, and fishing are performed. Due to these economic activities, the coastal areas receive an abundance of untreated solids and liquid waste. This area is rich in valuable marine algae such as the marine brown algae (Turbinaria conoides and Sargassum whitti), red algae (Gracilaria edulis, Hypnea musciformis, G. verrucosa, G. corticata; Sarconema filiforme, Kappaphycus alvarizii, and Acanthophora muscoides), and green algae (Ulva lactuca, $U$. reticulata, Caulerpa scalpelliformis, and Chaetomorpha linum).

\section{Materials and methods \\ Surface sediment sample collection}

In total, 24 samples of surface sediments were collected from the bottom of the water at various depths of 1-2 m from eight transects around the shelf zone of the research area during January 2020. The surface sediment samples were obtained using a Van Veen grab surface sampler. Stations 1, 4, 7, and 10 were located near the estuaries, boating areas, fish market, and other areas affected by various anthropogenic activities. Several sampling sites were selected to cover the entire study area. The samples were kept in a plastic container, packed in a cooler bag at $4{ }^{\circ} \mathrm{C}$, and transported to the research laboratory for sample processing. The texture, organic matter, and heavy metal concentrations of the surface sediment samples were analysed using standard procedures.

\section{Texture analysis}

Textural analyses were performed in the laboratory using the sieving and pipetting method. For the removal of organic matter, sediment samples were initially pretreated with $\mathrm{H}_{2} \mathrm{O}_{2}$ solution and the samples were wetsieved in a mechanical sieve shaker using a $62 \mu \mathrm{m}$-sized mesh for $15 \mathrm{~min}$. The samples that passed through the sieve shaker were identified as mud, while the retained sample on the sieve was identified as sand. The finer fraction of the mud was identified as silt and clay $(>0.063$ $\mathrm{mm}$ ) and determined using the pipette method. The sediment texture was classified based on the mud content classification proposed by $[29,30]$ and the modified classification by [31]. 
a
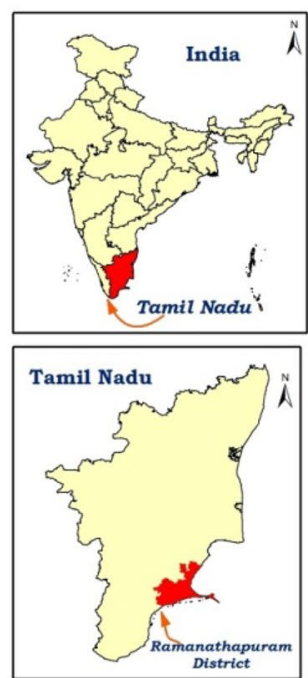

\begin{tabular}{l} 
District \\
Danathapu \\
\hline
\end{tabular}

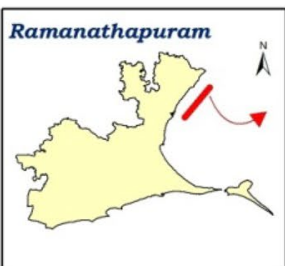

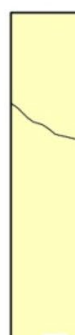

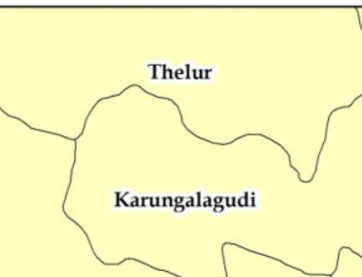

Mallanur
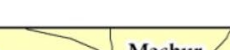

Machur

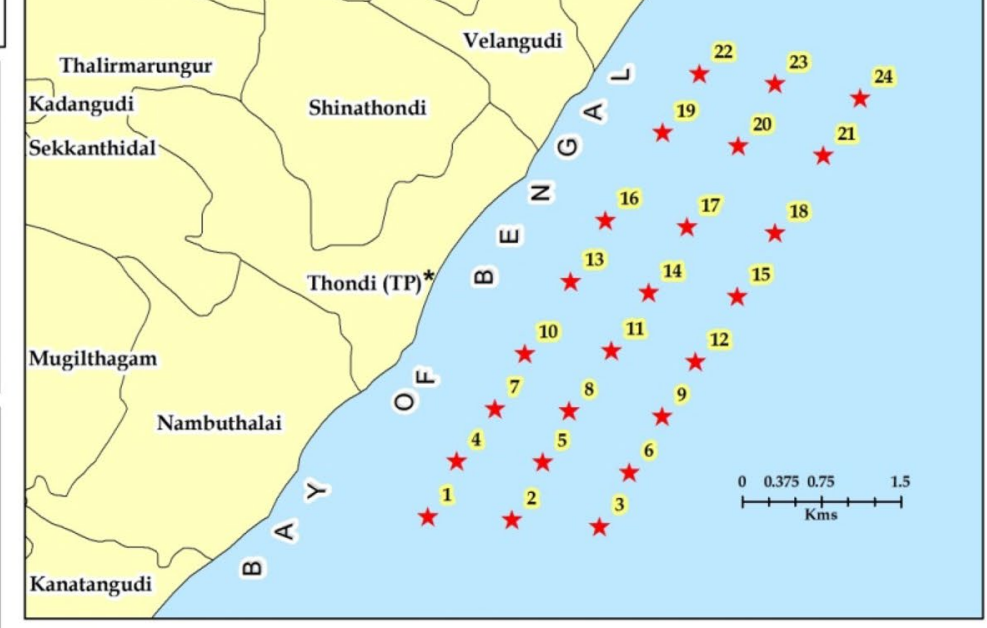

$\square$ Village Boundary $\star$ Sample Locations $\quad$ *Town Panchayat

b
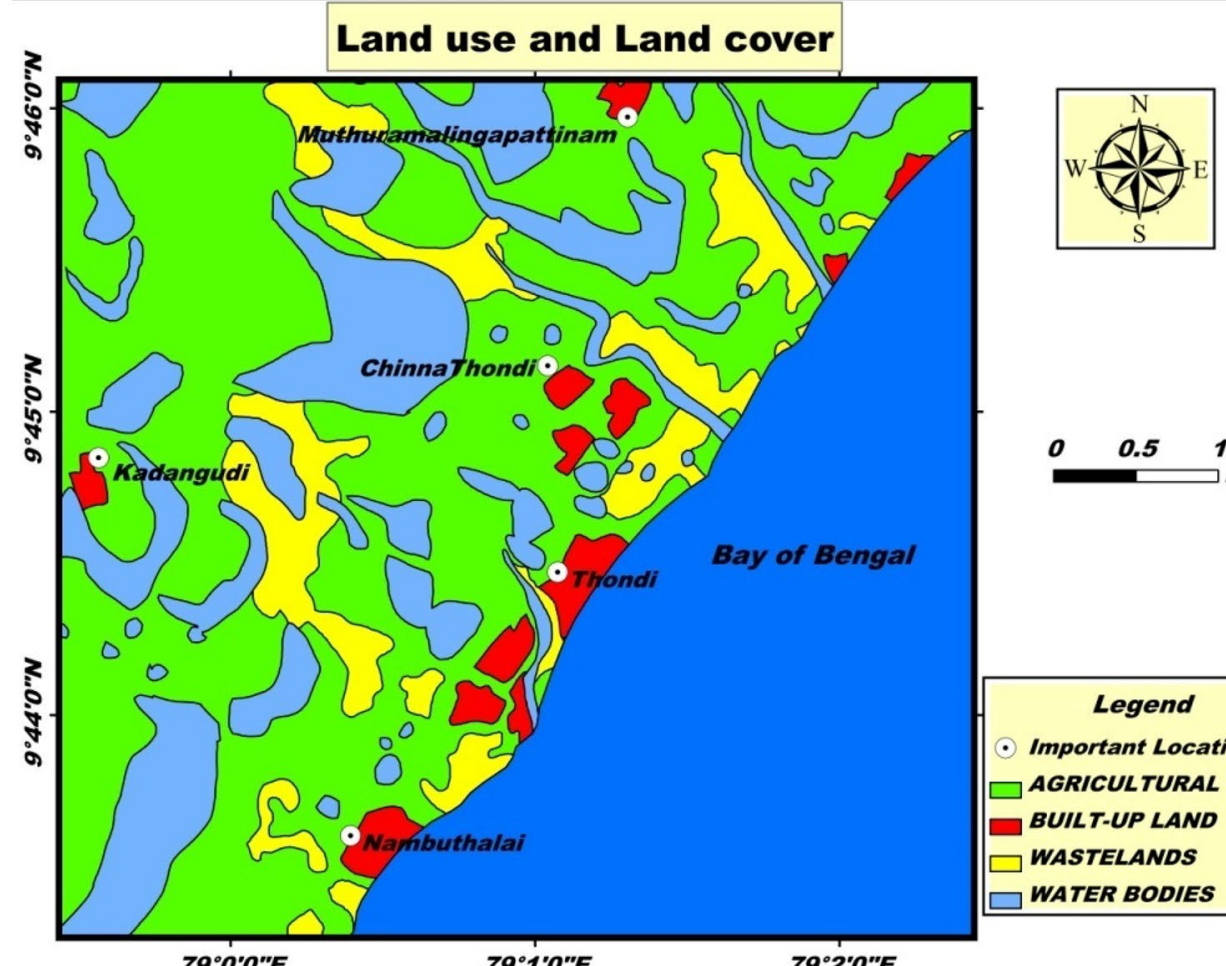

Legend

- Important Locations

AGRICULTURAL LAND

BUILT-UP LAND

WASTELANDS

WATER BODIES

Fig. 1 a Location of the research area with designated sampling points. b Map of land use and land cover of the study area 


\section{Geochemical analysis}

Approximately $1 \mathrm{~g}$ of surface sediment sample was treated with $\mathrm{HNO}_{3}, 30 \% \mathrm{H}_{2} \mathrm{O}_{2}$ and $\mathrm{HCl}$ to determine the concentration of elements $(\mathrm{Mn}, \mathrm{Al}, \mathrm{Cr}, \mathrm{Cu}, \mathrm{Pb}, \mathrm{Ni}$, and $\mathrm{Zn}$ ) according to the 3050B method [32]. After sample preparation, the measurement of metal concentrations was performed using ICP-MS located at the NGRI-CSIR analytical instrument facility in Hyderabad. $\mathrm{Cd}$ and $\mathrm{Fe}$ were measured separately using a flame atomic absorption spectrometer. In this study, the accuracy of the process with that of the analytical procedures was compared using reference sediment materials (MESS-1) provided by the National Research Council of Canada. By comparing the measured and certified values, the recovery values of the elements were as follows: $\mathrm{Fe}$ (97.93\%), $\mathrm{Al}(98.42 \%)$, Mn (95.70\%), Cr (97.37\%), Cu (96.41\%), Ni (94.78\%), Cd (92.22\%), $\mathrm{Pb}(100 \%)$, and $\mathrm{Zn}$ (97.91\%). The inaccurate percentage was less than $4 \%$.

\section{Assessment of sediment pollution levels}

The level of heavy metal contamination from both natural and anthropogenic sources in the Thondi coast, Palk Bay of Tamil Nadu, Southeast India was determined based on the complete assessment of sediment samples in the study area. Seven measurements, namely EF, CF, $\mathrm{C}_{\mathrm{d}}, \mathrm{mC}_{\mathrm{d}}, \mathrm{RI}, I_{\text {geo }}$, and $\mathrm{C}_{\mathrm{p}}$, were used to obtain the relative pollution level of the sampling sites.

\section{Enrichment factor}

Enrichment factor (EF) is used to analyse the impact of anthropogenic sources in the sediment and the level of contamination in the study area. The geochemical normalisation of the sediment heavy metal data in relation to the content of conservative elements such as $\mathrm{Al}$ was used to identify the anomalous metal concentration [3336]. The estimation of EF is based on the assessment of the trace element enrichment in the sediment [37]. It is defined based on the following formula [38]

$$
\mathrm{EF}=(\mathrm{Cx} / \mathrm{Al})_{\text {sample }} /(\mathrm{Cx} / \mathrm{Al})_{\text {background }},
$$

where $\mathrm{Cx}_{\text {Sample }}$ and $\mathrm{Cx}_{\text {background }}$ represent the concentration of selected metals ( $\mathrm{Fe}, \mathrm{Mn}, \mathrm{Cr}, \mathrm{Cu}, \mathrm{Ni}, \mathrm{Cd}, \mathrm{Pb}$, and $\mathrm{Zn})$ in the sediment samples. $(\mathrm{Cx} / \mathrm{Al})_{\text {background }}$ is the ratio of the background values of $\mathrm{Al}$. The EF values for $\mathrm{Fe}$ (56,300\%), $\mathrm{Al}$ (8.23\%), Mn (950 $\left.\mathrm{mgkg}^{-1}\right), \mathrm{Cr}$ (100 $\left.\mathrm{mgkg}^{-1}\right), \mathrm{Cu}\left(55 \mathrm{mgkg}^{-1}\right), \mathrm{Ni}\left(75 \mathrm{mgkg}^{-1}\right), \mathrm{Cd}(20$ $\left.\mathrm{mgkg}^{-1}\right), \mathrm{Pb}\left(12.5 \mathrm{mgkg}^{-1}\right)$, and $\mathrm{Zn}\left(70 \mathrm{mgkg}^{-1}\right)$ that were previously reported for sedimentary rocks were used as background values [39]. The results obtained were indicative of different levels of pollution. The elemental enrichment classification of the sediment is based on the following: (i) $0-1=$ background concentration or no enrichment; (ii) $1-3=$ minor, (iii) $3-5=$ moderate, (iv) $5-10=$ moderately severe, (v) $10-25=$ severe, (vi) $25-50=$ very severe, and (vii) $>50=$ extremely severe.

\section{Contamination factor}

Ref. [40] proposed the use of CF to assess the contamination status of the surface sediment based on the following equation:

$$
\begin{aligned}
\mathrm{CF}= & C_{\text {metal concentration in sediment }} / \\
& C_{\text {background background value of metal }} .
\end{aligned}
$$

The CF values according to the four classes are depicted as follows: (i) $\mathrm{CF}<1=$ low, (ii) $1<\mathrm{CF}<3=$ moderate, (iii) $3<\mathrm{CF}<6=$ considerable, and (iv) $\mathrm{CF}>6=$ very high.

\section{Degree of contamination}

The degree of contamination $\left(C_{\mathrm{d}}\right)$ represents the sum of all the $\mathrm{CF}$ values for all the sampling sites. It was previously proposed by [40] as shown below:

$$
C \mathrm{~d}=\sum_{\mathrm{i}=1}^{8} \mathrm{CF} .
$$

The degree of contamination is depicted as follows: (i) $C_{\mathrm{d}}<6=$ low, (ii) $6<C_{\mathrm{d}}<12=$ moderate, (iii) $12<C_{\mathrm{d}}<24=$ considerably high, and (iv) $C_{\mathrm{d}}>24=$ high.

\section{Modified contamination degree}

Modified contamination degree is the sum of all contamination factors for the element samples to the number of elements analysed. This measure was proposed by [41] to investigate an unlimited number of heavy metals and is represented in Eq. 4:

$$
\mathrm{mCd}=\frac{\left(\sum_{i=1}^{i=n} \mathrm{CF}\right)}{n},
$$

where $n$ is the number of analysed elements and $\mathrm{i}=\mathrm{i}^{\text {th }}$ element (or pollutant) examined and contamination factor $(\mathrm{CF})$. Modified contamination degree classifies the contamination level of sediment based on the following quantitative values: (i) $\mathrm{mC}_{\mathrm{d}}<1.5=$ nil to very low, (ii) $1.5 \leq \mathrm{m} C_{\mathrm{d}}<2=$ low, (iii) $2 \leq \mathrm{m} C_{\mathrm{d}}<4=$ moderate, (iv) $4 \leq \mathrm{m} C_{\mathrm{d}}<8=$ high, (v) $8 \leq \mathrm{m} C_{\mathrm{d}}<16=$ very high, (vi) $16 \leq \mathrm{m} C_{\mathrm{d}}<32=$ extremely high, and (vii) $\mathrm{mC}_{\mathrm{d}} \leq 32=$ ultra-high.

\section{Pollution load index}

The pollution load index (PLI) of a specific site or a zone is assessed according to the index described by [42]. This tool is used to assess the heavy metal pollution [43] and is calculated based on the formula shown below: 
PLI for a station $=\sqrt[n]{\mathrm{CF} 1 \times \mathrm{CF} 2 \times \mathrm{CF} 3 \ldots \ldots \ldots \mathrm{CFn}}$,

where $n$ is the number of heavy metals, CFs, CF is $C_{\text {metal }} / C_{\text {background }}$, $\left(C_{\text {metal }}\right)$ corresponds to the metal concentration of the sample, and $C_{\text {background }}$ is the background metal concentration:

PLI for zone $=\sqrt[n]{\text { Station } 1 \times \text { Station } 2 \ldots \ldots \times \text { Station } n}$.

\section{Potential ecological risk index (RI)}

Potential ecological risk index evaluates the environmental behaviour and characteristics of heavy metal contaminants in the sediments. This method was previously proposed by [40] and its primary objective is to specify the agents that cause contamination. The RI is the summation of all risk factors for the detection of heavy metal contaminants in the sediment. The RI is calculated based on the following equations:

$$
\begin{aligned}
& C_{\mathrm{r}}^{\mathrm{i}}=\frac{C^{i}}{C_{\mathrm{n}}^{\mathrm{i}}}, \\
& \mathrm{E}_{\mathrm{r}}^{\mathrm{i}}=\mathrm{T}_{\mathrm{r}}^{\mathrm{i}} \times C_{\mathrm{r}}^{\mathrm{i}}, \\
& R I=\sum_{i=1}^{n} \mathrm{~T}_{\mathrm{r}}^{\mathrm{i}} \times C_{\mathrm{r}}^{\mathrm{i}}=\sum_{i=1}^{n} \mathrm{~T}_{\mathrm{r}}^{\mathrm{i}} C^{i} / C_{\mathrm{n}}^{\mathrm{i}},
\end{aligned}
$$

where RI is the total potential ecological risk of individual heavy metal; $E_{r}^{i}$ is the potential ecological risk of individual heavy metal; and $\mathrm{T}_{\mathrm{r}}^{\mathrm{i}}=$ toxic response factor which represents the toxicity of a particular trace element. Hakanson proposed a standardised toxic response factor of $5,1,2,5,5$, and 30 for $\mathrm{Cu}, \mathrm{Zn}, \mathrm{Cr}, \mathrm{Ni}, \mathrm{Pb}$, and $\mathrm{Cd}$, respectively. $C^{i}$ is the measured concentration of metal $\mathrm{n}$ in marine sediments; and $C_{\mathrm{n}}^{\mathrm{i}}$ is the standard value of metal $n$ in the marine sediments. The conditions used to denote the risk factors and RI according to [40] are classified into nine categories of ecological risk as follows: (i) $<40=$ low, (ii) $40<\mathrm{E}_{\mathrm{r}}^{\mathrm{i}}<80=$ moderate, (iii) $80<\mathrm{E}_{\mathrm{r}}^{\mathrm{i}}<160=$ considerably high, (iv) $160<\mathrm{E}_{\mathrm{r}}^{\mathrm{i}}$ $320=$ high, (v) $\mathrm{E}_{\mathrm{r}}^{\mathrm{i}}>320=$ very high, (vi) $\mathrm{RI}<95=$ low, (vii) $95<\mathrm{RI}<190=$ moderate, (viii) $190<\mathrm{RI}<380=$ considerably high, and (ix) RI $>380=$ very high.

\section{Geoaccumulation index (lgeo)}

$I_{\text {geo }}$ is used to analyse the level of pollution of trace elements and the contamination degree in marine sediments [44]. It was initially described by [46] as follows:

$$
I_{\text {geo }}=\log _{2}\left[\left(C_{\mathrm{n}} /\left(1.5 \times B_{\mathrm{n}}\right)\right]\right.
$$

where $C_{n}=$ the trace metals calculated (measured concentrations of the sediment samples, respectively) and $B_{\mathrm{n}}=$ background value (average value of crustal abundance) of a particular element. To decrease the possibility of variation in the background values for a specific trace element in the environment and minor anthropogenic influences, the concentration of each geochemical background value is multiplied by the factor of 1.5 [45]. The sediment classification is based on the $I_{\text {geo }}$ value [46] as follows: (i) $I_{\text {geo }}>5=$ extreme contamination, (ii) $4-5=$ strong to extreme contamination, (iii) $3-4=$ strong contamination, (iv) $2-3=$ moderate to strong contamination, (v) $1-2=$ moderate contamination, (vi) $0-1=$ uncontaminated to moderate contamination, (vii) $<0=$ uncontaminated.

\section{Potential contamination index}

The potential contamination index is calculated using the formula described below:

$$
C \mathrm{p}=\frac{(\text { Metal })_{\text {sample Max }}}{(\text { Metal })_{\text {background }}}
$$

where (Metal) $)_{\text {sample Max }}$ is the highest concentration value of an element in the sediment, and (Metal) Background $_{\text {rep- }}$ resents the background concentration value of the element. This method was proposed by [47, 48], whereby the $C_{\mathrm{p}}$ values are classified into three levels of contamination: (i) $C_{\mathrm{p}}<1=$ low, (ii) $1<C_{\mathrm{p}}<3=$ moderate, and (iii) $C_{\mathrm{p}}>3=$ severe.

\section{Statistical analysis}

Multivariate statistical analysis method such as Pearson's correlation coefficient, PCA, and Cluster analysis were used to determine the relationship between the contaminants in the sediment and their potential sources. The statistical software IBD-SPSS (version 20.0) was employed in this present study.

\section{GIS analysis}

The inverse distance weighted (IDW) approach using ArcGIS 10.2 software was employed for the analysis of the spatial distribution characteristics of heavy metals in the sediments.

\section{Results}

The results of the physicochemical parameters analysed during sample collection in the study area are displayed in Table 1. In total, 24 samples of surface sediment were collected from the Thondi coast of Palk Bay for analysis. The basic descriptive statistics (min, max, average, and 
Table 1 Physicochemical parameters of the Thondi coastal seawater

\begin{tabular}{llc}
\hline S. no. & Physicochemical parameters & Average values \\
\hline 1 & EC $(\mu \mathrm{s})$ & 33.9 \\
2 & Salinity (psu) & 32.9 \\
3 & $\mathrm{pH}$ & 7.85 \\
4 & $\mathrm{TDS}(\mathrm{ppm})$ & 17.6 \\
5 & Atmospheric temperature $\left({ }^{\circ} \mathrm{C}\right)$ & 30.6 \\
6 & Surface water temperature $\left({ }^{\circ} \mathrm{C}\right)$ & 27.6 \\
7 & $\mathrm{DO}(\mathrm{mg} / \mathrm{l})$ & 5.40 \\
8 & $\mathrm{BOD}(\mathrm{mg} / \mathrm{l})$ & 0.99 \\
\hline
\end{tabular}

SD) for the heavy metal concentrations measured at 24 locations are summarised in Table 2.

\section{Grain size}

The shelf region of the study area contains two different types of sediment, namely slightly muddy sand and muddy sand. The samples collected from stations 4,5 , 6 , and 7 were slightly muddy sand and those collected from stations 1, 2, 3, 8-24 were muddy sand sediments (Fig. 2).

\section{Enrichment factors}

The EF values for the heavy metal contaminants in the sediments are listed in Fig. 3 and Table 3. The EF value of the surface sediments in the study area was $0.41-1.09$ (average 0.65) (Fe), 0.30-0.89 (average 0.50) (Mn), 1.253.38 (average 2.00) (Cr), 0.41-1.31 (average 0.67) $(\mathrm{Cu})$, 0.18-0.40 (average 0.25) (Ni), 1.52-9.97 (average 4.12) (Cd), 0.52-1.21 (average 0.76) (Pb), and 1.77-3.98 (average 2.48) ( $\mathrm{Zn})$. Cd displayed the highest EF value among the eight metals investigated and was classified as moderately severe enrichment with an average value of 4.12. Zn and $\mathrm{Cr}$ displayed a minor enrichment (average values of 2.48 and 2.00, respectively), while $\mathrm{Ni}, \mathrm{Mn}, \mathrm{Fe}, \mathrm{Cu}$, and $\mathrm{Pb}$ were classified as no enrichment (average values of 0.25 , $0.50,0.65,0.67$, and 0.76 , respectively).

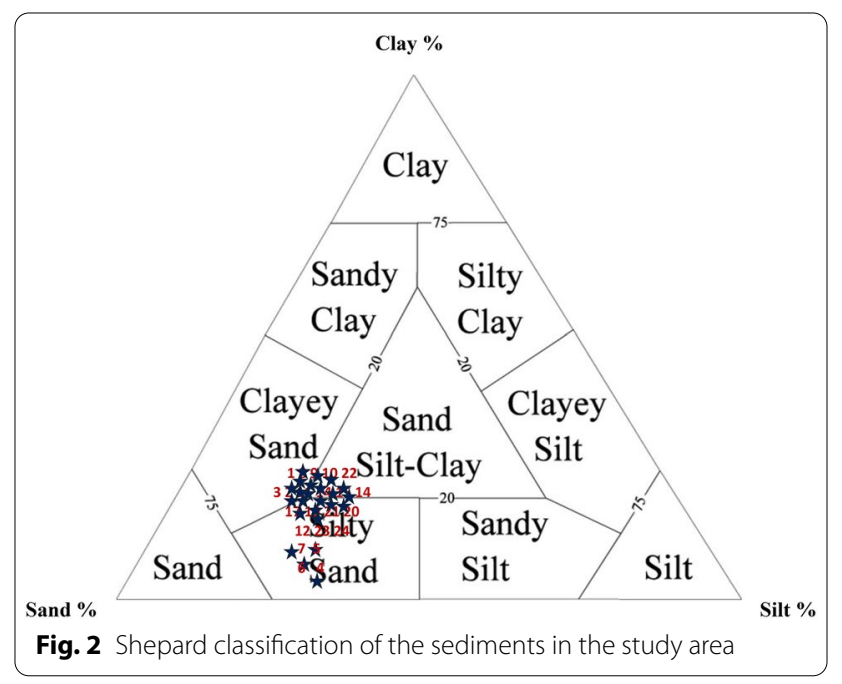

\section{Contamination factor}

The contamination factor (CF) values for the heavy metals in the sediments are shown in Table 3. The average $\mathrm{CF}$ value for $\mathrm{Ni}$ (0.37), $\mathrm{Mn}$ (0.72), Fe (0.94), and $\mathrm{Cu}(0.99)$ was $<1$, thus indicating that the sediment samples had a low level of contamination. The average $\mathrm{CF}$ value of $\mathrm{Pb}$ (1.13) and $\mathrm{Cr}$ (2.90) was $1-3$, thereby indicating that the sediments were moderately contaminated. The average CF value of $\mathrm{Zn} \mathrm{(3.61)} \mathrm{and} \mathrm{Cd}$ (5.83) was 3-6 and this indicated that the sediments had considerable contamination. In this study, the average CF values of heavy metals were ranked based on the following order: $\mathrm{Ni}<\mathrm{Mn}<\mathrm{F}$ $\mathrm{e}<\mathrm{Cu}<\mathrm{Pb}<\mathrm{Cr}<\mathrm{Zn}<\mathrm{Cd}$. The changes in $\mathrm{CF}$ values at different locations are displayed in Fig. 4.

\section{Geoaccumulation index}

The calculated $I_{\text {geo }}$ values of the heavy metals are shown in Fig. 5 and Table 3. The $I_{\text {geo }}$ value of the surface sediments in the study area was 9.20-9.37 (average 9.29) (Fe), 5.43-5.75 (average 5.63) ( $\mathrm{Mn}), 4.19-4.4$ (average 4.28) (Cr), 3.06-3.49 (average 3.3) $(\mathrm{Cu}), 3-3.25$ (average $3.1)(\mathrm{Ni}),-1.13$ to -0.49 (average -0.8$)(\mathrm{Cd}), 1.93-2.21$ (average 2.1) (Pb), and 4-4.14 (average 4.1) ( $\mathrm{Zn})$. The results were classified as "extremely contaminated" for Fe,

Table 2 Concentration of heavy metals in the sediments (min, max, average, SD)

\begin{tabular}{|c|c|c|c|c|c|c|c|c|}
\hline Elements (mg kg ${ }^{-1}$ ) & $\mathrm{Fe}$ & $M n$ & $\mathrm{Cr}$ & $\mathrm{Cu}$ & $\mathrm{Ni}$ & $\mathrm{Cd}$ & $\mathrm{Pb}$ & $\mathrm{Zn}$ \\
\hline Minimum & 42,516 & 425 & 231 & 31 & 20.1 & 0.6 & 10.2 & 214 \\
\hline Maximum & 62,413 & 896 & 378 & 84 & 35.6 & 2.5 & 19.5 & 298 \\
\hline Average & $52,802.3$ & 686.1 & 290.3 & 54.7 & 27.7 & 1.2 & 14.1 & 252.9 \\
\hline SD & 6213.3 & 141 & 42.3 & 16.1 & 3.0 & 0.5 & 2.5 & 21.8 \\
\hline CV [56] & 56,300 & 950 & 100 & 55 & 75 & 20 & 12.5 & 70 \\
\hline
\end{tabular}

SD standard deviation, $C V$ crustal value 

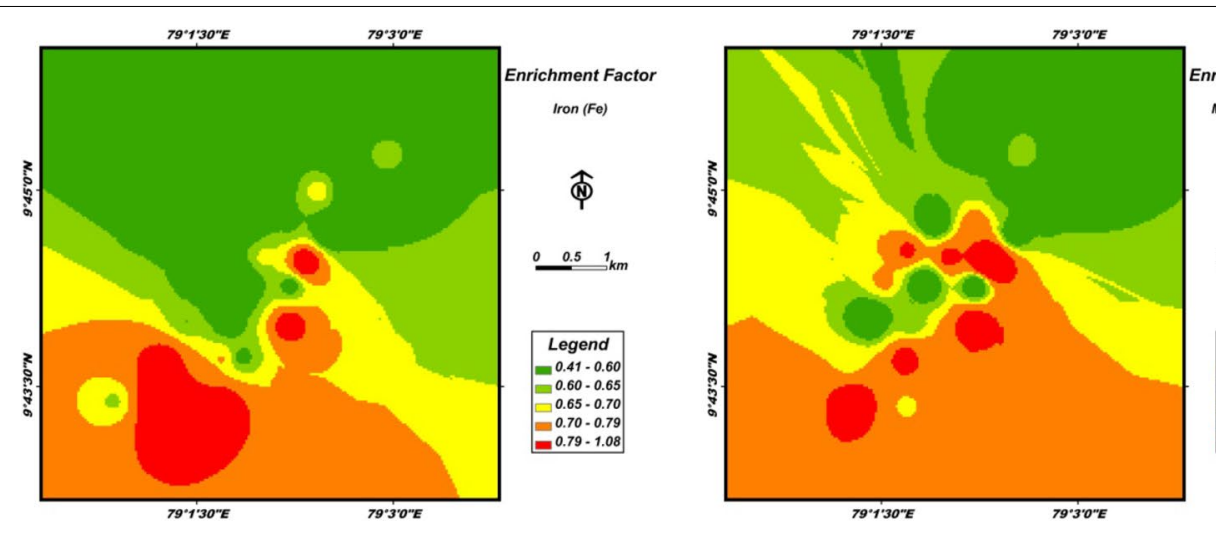

Enrichment Factor

Manganese (Mn)
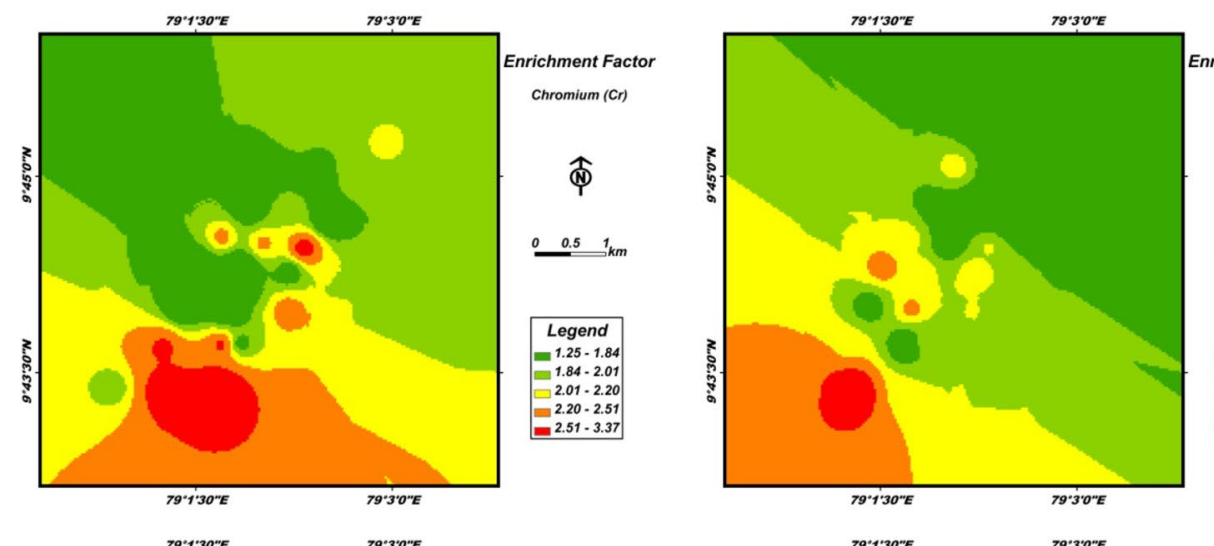

Enrichment Factor

Copper (Cu)
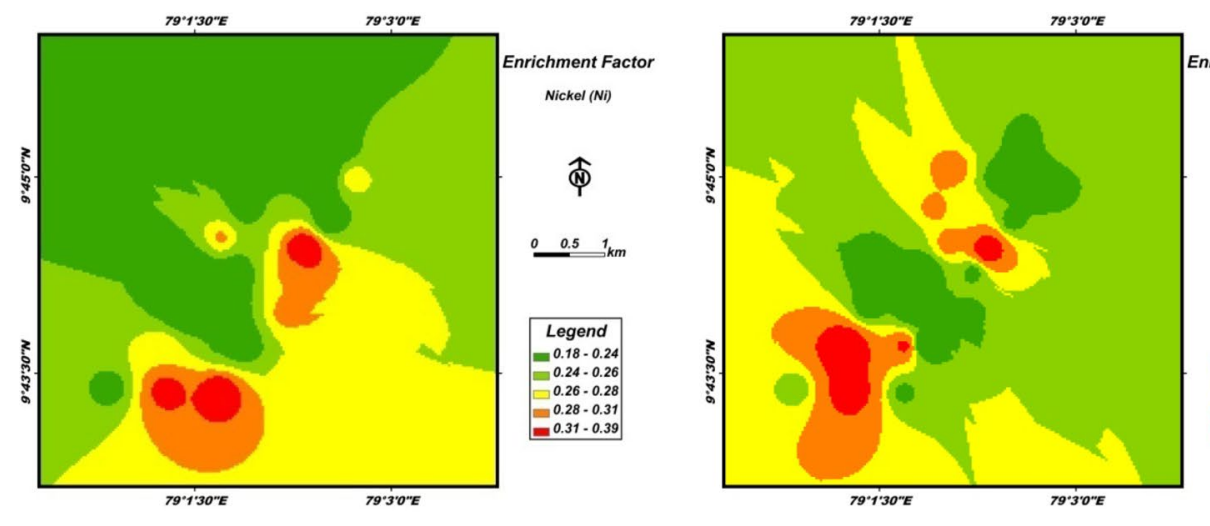

\section{企}

$0.0 .5 \mathrm{~km}$
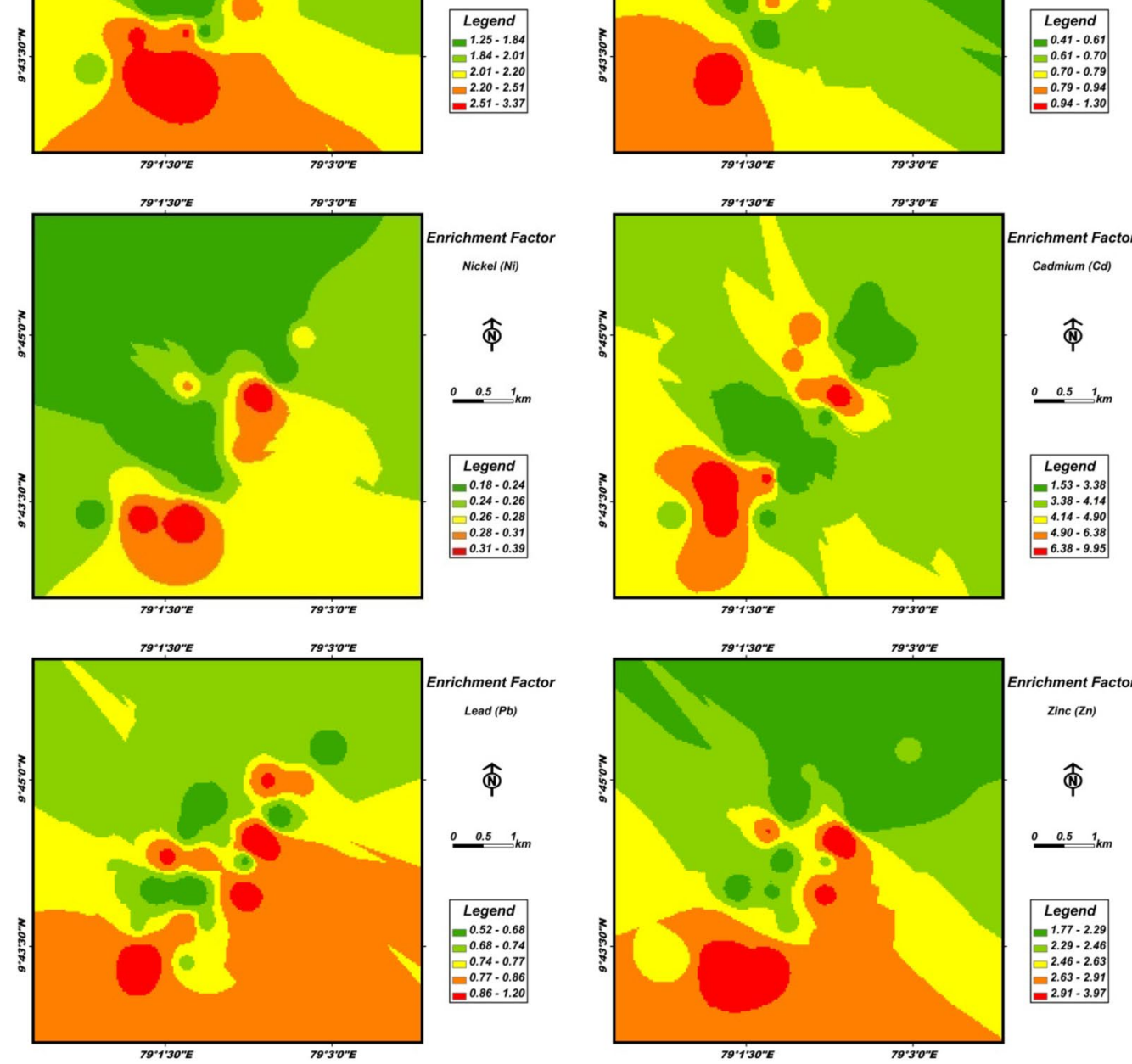

Enrichment Factor

Zinc (Zn)

市

$0.0 .5 \mathrm{~km}$

Legend

\begin{tabular}{|r|}
$\mathbf{E} 1.77 \cdot 2.29$ \\
$\mathbf{2} 2.29 \cdot 2.46$
\end{tabular}

$\begin{array}{r}\mathbf{2} 2.29-2.46 \\ \hline 2.46 \cdot 2.63\end{array}$

$\begin{array}{r}2.63 \cdot 2.91 \\ \hline \\ \\ 2.91 \cdot 3.97 \\ \hline\end{array}$

Fig. 3 Distribution maps of enrichment factor for heavy metals in the surface sediments 
Table 3 EF, CF, I geo, $E_{r}^{i}$, and RI (min, max, and ave) values of the heavy metals contaminants in the sediments

\begin{tabular}{|c|c|c|c|c|c|c|c|c|c|}
\hline Index & & $\mathrm{Fe}$ & $M n$ & $\mathrm{Cr}$ & $\mathrm{Cu}$ & $\mathrm{Ni}$ & $\mathrm{Cd}$ & $\mathrm{Pb}$ & $\mathrm{Zn}$ \\
\hline \multirow[t]{3}{*}{$E F$} & Min & 0.41 & 0.30 & 1.25 & 0.41 & 0.18 & 1.52 & 0.52 & 1.77 \\
\hline & Max & 1.09 & 0.89 & 3.38 & 1.31 & 0.40 & 9.97 & 1.21 & 3.98 \\
\hline & Ave & 0.65 & 0.50 & 2.00 & 0.67 & 0.25 & 4.12 & 0.76 & 2.48 \\
\hline \multirow[t]{3}{*}{$C F$} & Min & 0.76 & 0.45 & 2.31 & 0.56 & 0.27 & 2.75 & 0.82 & 3.06 \\
\hline & Max & 1.11 & 0.94 & 3.78 & 1.53 & 0.48 & 12.25 & 1.56 & 4.26 \\
\hline & Ave & 0.94 & 0.73 & 2.90 & 0.99 & 0.37 & 5.83 & 1.13 & 3.61 \\
\hline \multirow[t]{3}{*}{$I_{\text {geo }}$} & Min & 9.2 & 5.43 & 4.19 & 3.06 & 3 & -1.13 & 1.93 & 4 \\
\hline & Max & 9.37 & 5.75 & 4.4 & 3.49 & 3.25 & -0.49 & 2.21 & 4.14 \\
\hline & Ave & 9.29 & 5.63 & 4.28 & 3.28 & 3.14 & -0.85 & 2.06 & 4.07 \\
\hline \multirow[t]{3}{*}{$E_{\mathrm{r}}^{\mathrm{i}}$} & Min & - & - & 1 & 3 & 1 & 82.5 & 4 & 3 \\
\hline & Max & - & - & 3 & 8 & 2.015 & 367.5 & 8 & 4 \\
\hline & Ave & - & - & 2.08 & 5 & 1.81 & 174.88 & 5.58 & 3.71 \\
\hline $\mathrm{Rl}$ & - & - & - & 48 & 119 & 44.3 & 4197 & 135 & 87 \\
\hline
\end{tabular}

$\mathrm{Mn}$, and Cd, "strongly to extremely contaminated" for $\mathrm{Cr}$ and $\mathrm{Zn}$, "strongly contaminated" for $\mathrm{Ni}$ and $\mathrm{Cu}$, "moderately to strongly contaminated" for $\mathrm{Pb}$ in this study area. The heavy metal pollution level tends to be higher in the study area, whereby, the average $I_{\text {geo }}$ values of metals were ranked based on the following order: $\mathrm{Pb}<\mathrm{Ni}<\mathrm{Cu}<$ $\mathrm{Zn}<\mathrm{Cr}<\mathrm{Cd}<\mathrm{Mn}<\mathrm{Fe}$. These results suggest that anthropogenic sources have considerable effects on $\mathrm{Fe}, \mathrm{Mn}, \mathrm{Cd}$, $\mathrm{Cr}, \mathrm{Zn}, \mathrm{Cu}, \mathrm{Ni}$, and $\mathrm{Pb}$ in the sediments and therefore, require more attention for the monitoring of $\mathrm{Fe}, \mathrm{Mn}, \mathrm{Cd}$, $\mathrm{Zn}, \mathrm{Cr}$, and $\mathrm{Cu}$ pollution.

\section{Potential ecological risk factor $\left(\mathrm{E}_{\mathrm{r}}^{\mathrm{i}}\right)$ and index (RI)}

The results of the potential ecological risk factor, $E_{r}^{i}$, and RI for heavy metals in the sediments are shown in Table 3. The average $E_{r}^{i}$ values of $\mathrm{Cu}(5), \mathrm{Zn}(4), \mathrm{Cr}$ (2), Ni (1.84), and $\mathrm{Pb}(6)$ was less than 40 , whereby the ecological risk for each heavy metal is classified as low-potential. In contrast, there was a high ecological risk for Cd (174.88) in the sediments that were mainly due to the discharge of municipal sewage waste in the study area. The RI values of $\mathrm{Zn}$ (87), $\mathrm{Cu}$ (119), and $\mathrm{Pb}$ (135) indicated that there was a considerable ecological risk, followed by $\mathrm{Ni}$ (44.35) and $\mathrm{Cr}$ (48) which indicated a moderate ecological risk, and lastly, Cd (4197) which indicated a very high ecological risk.

\section{Contamination degree (Cd), modified contamination degree $(\mathrm{mCd})$, pollution load index (PLI), and potential contamination index $(\mathrm{Cl})$}

The calculated values of $C_{\mathrm{d}}, \mathrm{m} C_{\mathrm{d}}$, PLI, and $C_{\mathrm{p}}$ values for the heavy metals are shown in Table 4 . The $C_{d}$ values within the range of $12<C_{d}<24$ (minimum-14.62, maximum-23.9, and average-17.429) indicated that there was a substantial degree of contamination at all the stations, in which the sediments in the study area had a considerable degree of contamination. The overall degree of pollution at different sampling sites and $C_{\mathrm{d}}$ data are shown in Table 4. The results indicate that the degree of contamination was nil to very low at nine stations, namely stations 3 (15.35), 6 (14.72), 7 (15.18), 10 (15.1), 11 (14.7), 12 (15.1), 18 (15.3), 20 (14.62), and 21 (14.84), and moderate at stations 1 (19.82), 2 (19.36), 4 (23.9), 5 (21.53), 8 (16.52), 9 (16.14), 13 (16.85), 14 (19.63), 15 (18.51), 16 (19.12), 17 (17.17), 19 (22.27), 22 (17.27), 23 (18.07), and 24 (17.25). The main factors affecting the moderate contamination $\mathrm{mC}_{\mathrm{d}}$ values of stations $1,2,4,5$, $8,9,13,14,15,16,17,19,22,23$, and 24 were based on the CF values of $\mathrm{Cr}$ (3.23), $\mathrm{Cd}$ (4.18), and $\mathrm{Zn}$ (2.65) that were attributed to the anthropogenic pollution at these sites. The average value of $m C_{d}$ was less than 1 , thus indicating that the studied areas have been severely affected by anthropogenic contamination. The PLIs of the heavy metals are shown in Table 4 and the values ranged from 10.30 to 16.74 , with an average of 11.97 . These results revealed that the sediments in the study area were polluted by heavy metals. [42] reported that the PLI values were less than 1 for the heavy metals in all the sampling stations, thus indicating that the levels of the heavy metals investigated in this study were within the baseline level for all the stations. For instance, the PLI values for all the zones investigated ranged from 0.05 to 2.30. The value of $\mathrm{Cd}$ was higher (41) due to the effects of external sources such as industrial activities, agricultural runoff, and other anthropogenic contaminants. 

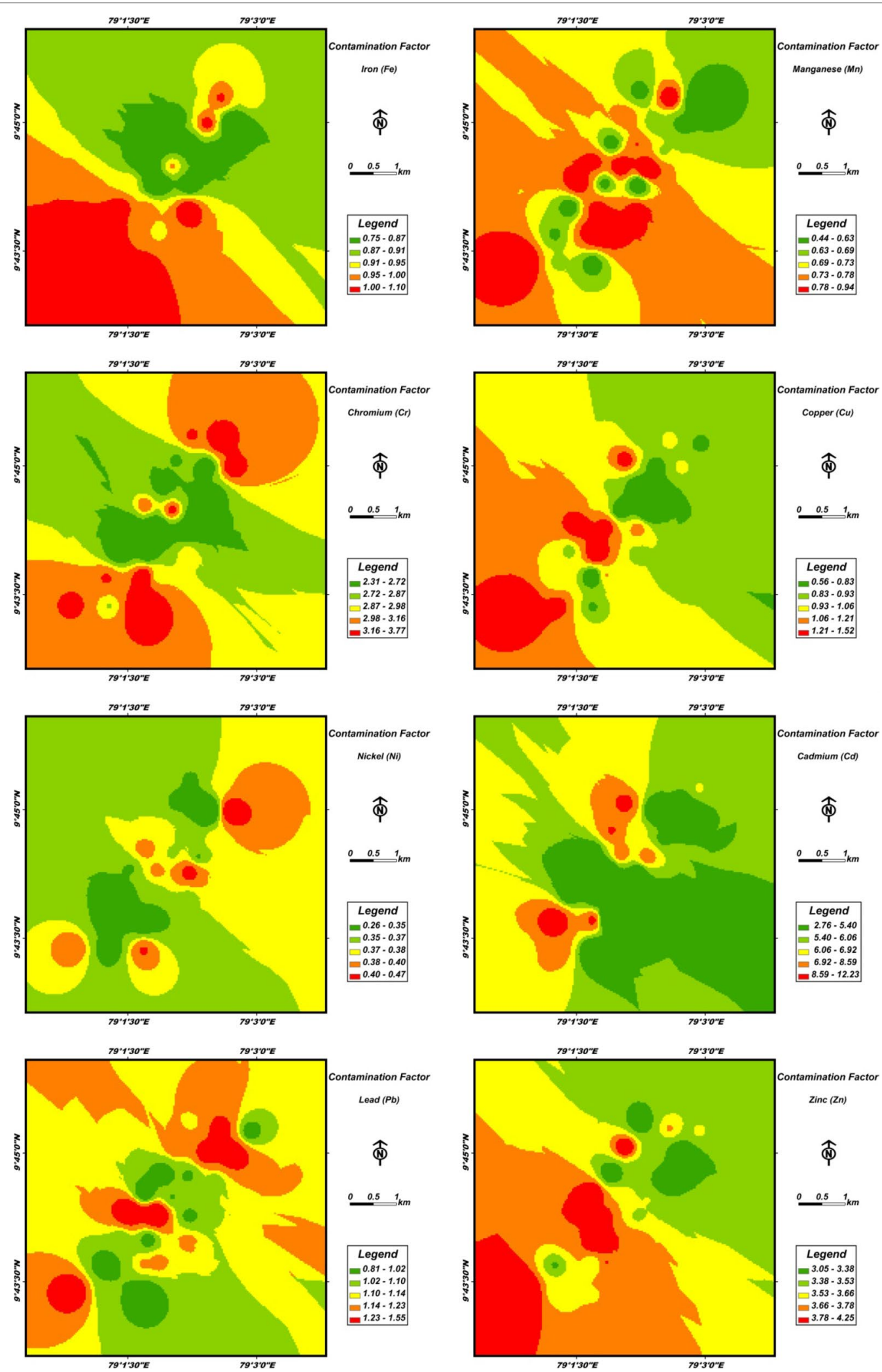

Fig. 4 Distribution maps of contamination factors for heavy metals in the surface sediments

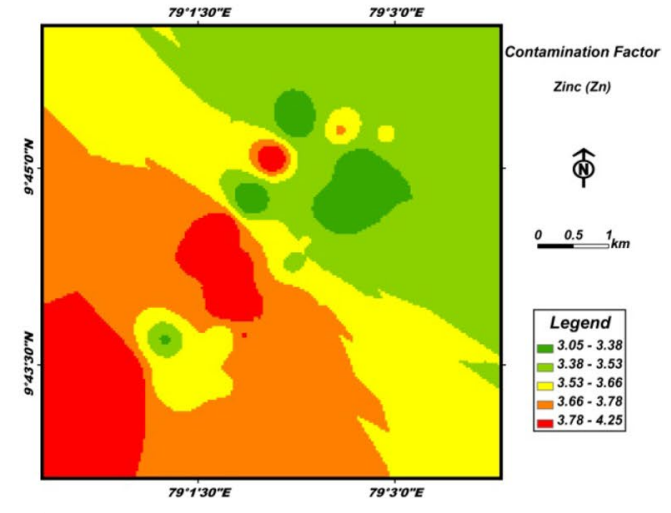



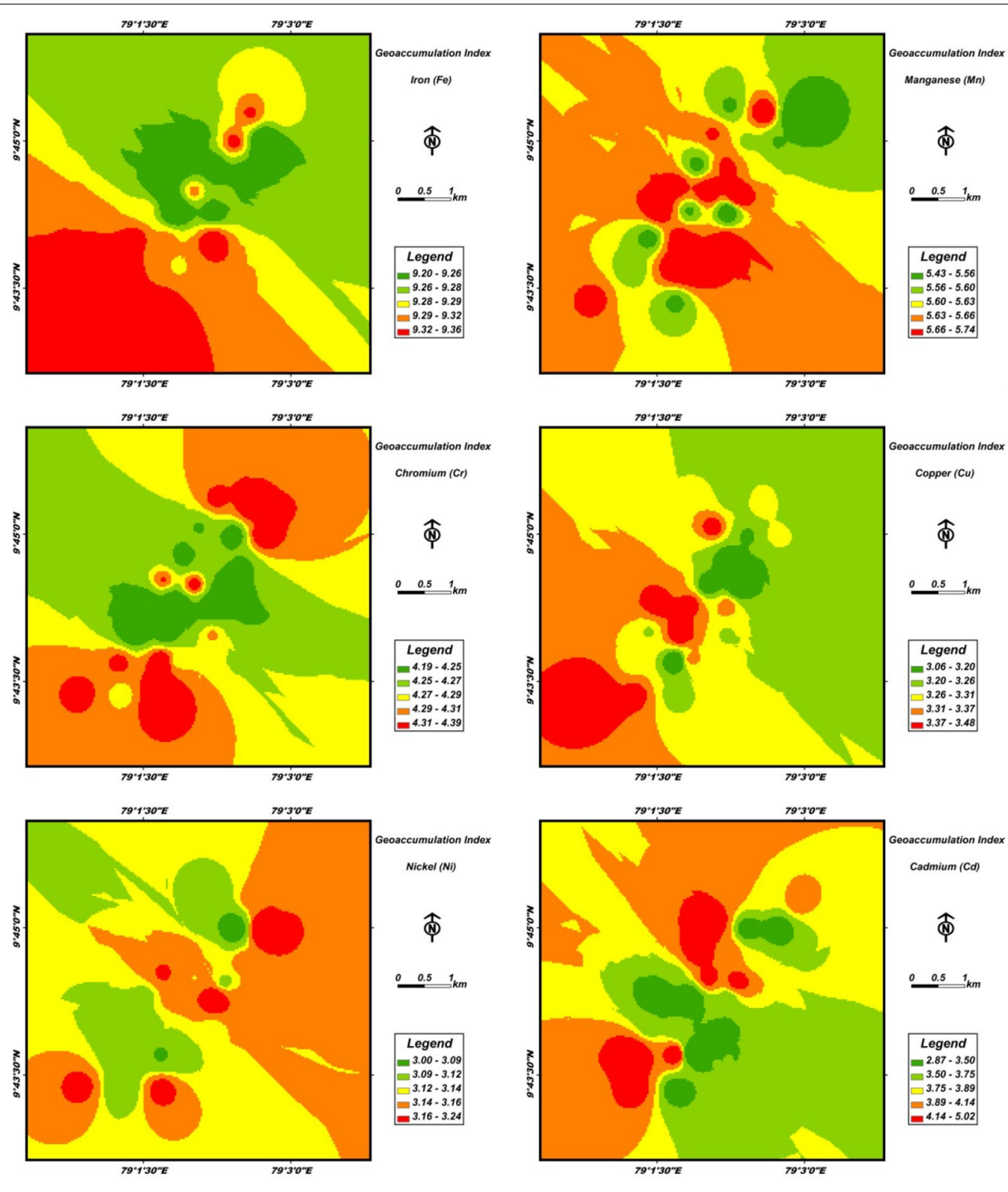

Cadmium (Cd)
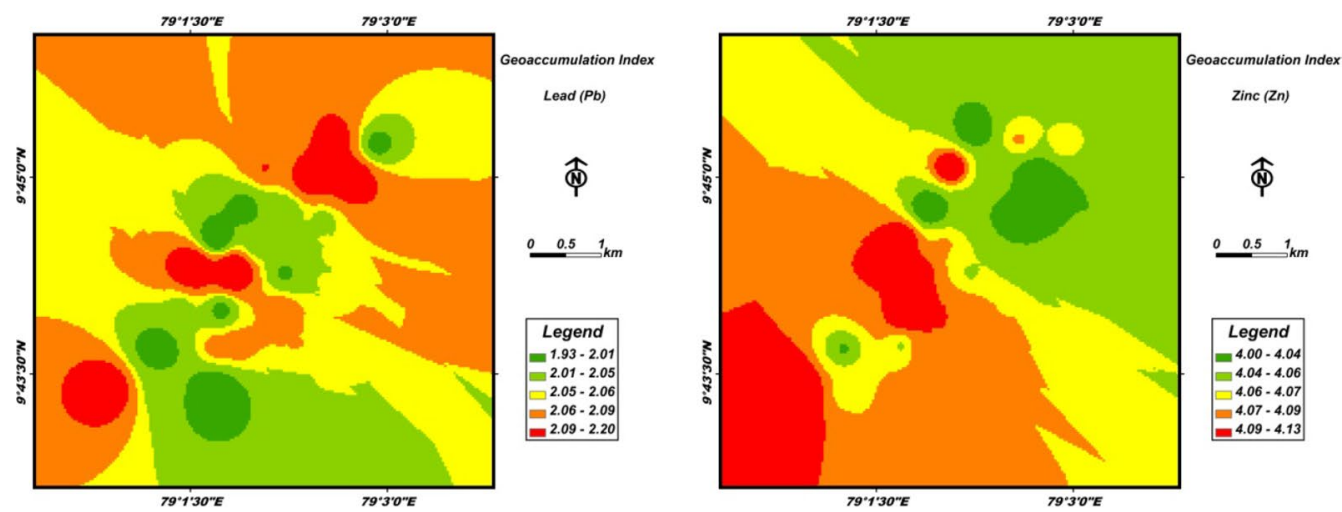

Fig. 5 Distribution maps of $I_{\text {geo }}$ for the heavy metals in the surface sediments 
כ

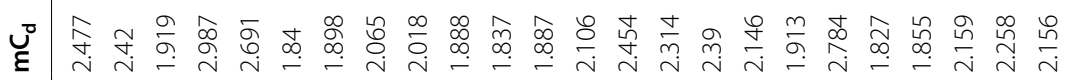

U

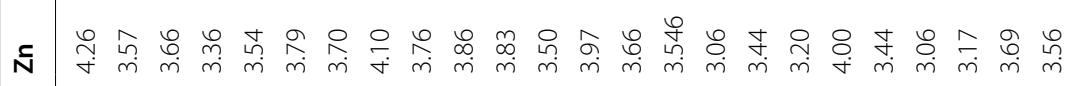

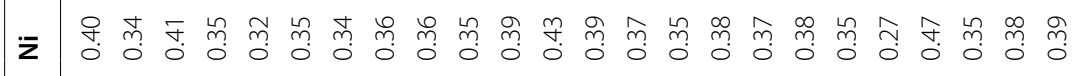

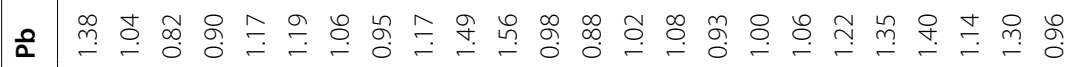

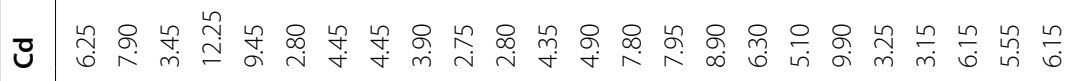

矛

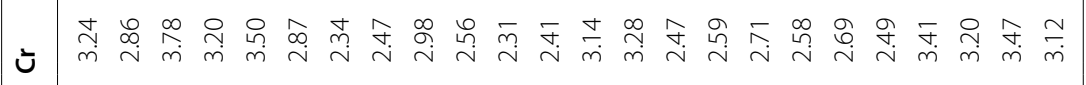

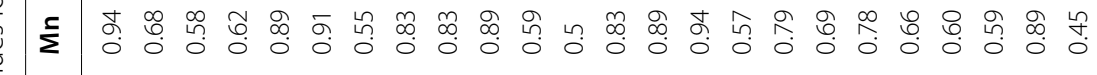

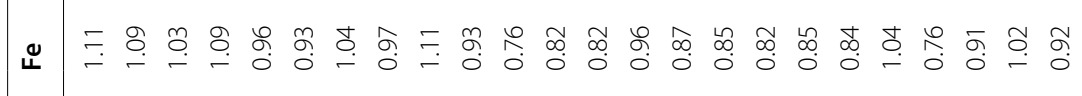


Table 5 Correlation coefficient $(R)$ values $(p<0.05)$ between different metals and sand (\%), mud (\%), and OM in the marine sediments

\begin{tabular}{|c|c|c|c|c|c|c|c|c|c|c|}
\hline Corre & $(p<0.0$ & & & & & & & & & \\
\hline .001 & & & & & & & & & & Mud \\
\hline .648 & .645 & & & & & & & & & $\mathrm{OM}$ \\
\hline .226 & .239 & .977 & & & & & & & & $\mathrm{Fe}$ \\
\hline .963 & .967 & .344 & .310 & & & & & & & $\mathrm{Mn}$ \\
\hline .673 & .678 & .969 & .182 & .428 & & & & & & $\mathrm{Cr}$ \\
\hline .748 & .739 & .420 & .911 & .499 & .180 & & & & & $\mathrm{Cu}$ \\
\hline .507 & .508 & .832 & .024 & .276 & .167 & .414 & & & & $\mathrm{Ni}$ \\
\hline .693 & .688 & .669 & .455 & .864 & .392 & .321 & .263 & & & $\mathrm{Cd}$ \\
\hline .996 & .995 & .577 & .596 & .197 & .476 & .085 & .844 & .063 & & $\mathrm{~Pb}$ \\
\hline .962 & .964 & .774 & .181 & .006 & .777 & .002 & .653 & .412 & .381 & $\mathrm{Zn}$ \\
\hline Sand & Mud & $\mathrm{OM}$ & $\mathrm{Fe}$ & $\mathrm{Mn}$ & $\mathrm{Cr}$ & $\mathrm{Cu}$ & $\mathrm{Ni}$ & $\mathrm{Cd}$ & $\mathrm{Pb}$ & \\
\hline
\end{tabular}

\section{Pearson's correlation matrix}

Pearson's correlation analysis defines the relationship between the heavy metals and their major contributors in the environment [49-51]. Pearson's correlation coefficients for sand, mud, $\mathrm{OM}, \mathrm{Fe}, \mathrm{Mn}, \mathrm{Cr}, \mathrm{Cu}, \mathrm{Ni}, \mathrm{Cd}, \mathrm{Pb}$, and $\mathrm{Zn}$ components are shown in Table 5. Sediment sand, mud, and OM displayed a strong positive correlation with all the elements investigated. For instance, Fe was strongly correlated with $\mathrm{Cu}\left(r^{2}=0.911\right), \mathrm{Cd}\left(r^{2}=0.455\right)$, and $\mathrm{Pb}\left(r^{2}=0.596\right)$ and weakly correlated with $\mathrm{Cr}, \mathrm{Ni}, \mathrm{Mn}$, and $\mathrm{Zn}$. On the other hand, Mn was strongly correlated with $\mathrm{Cr}\left(r^{2}=0.428\right), \mathrm{Cu}\left(r^{2}=0.499\right)$, and $\mathrm{Cd}\left(r^{2}=0.864\right)$ and weakly correlated with $\mathrm{Pb}, \mathrm{Ni}$ and $\mathrm{Zn}$. Additionally, $\mathrm{Cr}$ was strongly correlated with $\mathrm{Pb}\left(r^{2}=0.476\right)$, and $\mathrm{Zn}$ $\left(r^{2}=0.777\right)$ and weakly correlated with $\mathrm{Cu}\left(r^{2}=0.180\right)$, $\mathrm{Cd}\left(r^{2}=0.392\right)$, and $\mathrm{Ni}\left(r^{2}=0.167\right)$, while Ni was strongly correlated with $\mathrm{Pb}\left(r^{2}=0.844\right)$, and $\mathrm{Zn}\left(r^{2}=0.653\right)$ and weakly correlated with $\mathrm{Cd}\left(r^{2}=0.263\right)$.

\section{Principal component analysis/factor analysis, Q-mode cluster}

Multivariate analysis is commonly used to distinguish factors such the natural and anthropogenic contributions of the elements according to the various levels of relationship $[17,18,50-52]$. In this study, PCA/FA was employed to ascertain possible relationships of the variables and their input sources among the pollutants. The KaiserMeyer-Olkin (KMO) and Bartlett's values obtained in the study were 0.624 and $72(\mathrm{df}=24, p<0.001)$, respectively, thereby indicating that PCA/FA could be used for the reduction of dimensions. FA performed on the PCs and three VFs shows eigenvalue $>1$ that explains the quality of the sediments $[53,54]$.

The PCA/FA plots for various parameters investigated in this study were obtained using the rotated matrix analysis and varimax normalisation was used to calculate
Table 6 The result of PCA/FA for entire data set

\begin{tabular}{lccc}
\hline & PC1 & PC2 & PC3 \\
\hline Component matrix & & & \\
Eigen value & & & \\
\% of Variance & 2.463 & 2.023 & 1.270 \\
Cumulative \% & 2.034 & 14.686 & 49.965 \\
Loading of variances & 1.321 & & 64.646 \\
$\mathrm{Fe}$ & -0.178 & $0.771^{\mathrm{b}}$ & \\
$\mathrm{Mn}$ & 0.329 & $0.680^{\mathrm{b}}$ & 0.017 \\
$\mathrm{Cr}$ & -0.371 & 0.211 & 0.208 \\
$\mathrm{Cu}$ & 0.270 & 0.126 & $0.811^{\mathrm{b}}$ \\
$\mathrm{Ni}$ & 0.123 & -0.590 & $0.676^{\mathrm{b}}$ \\
$\mathrm{Cd}$ & $0.568^{\mathrm{b}}$ & 0.293 & -0.085 \\
$\mathrm{~Pb}$ & 0.206 & $0.612^{\mathrm{b}}$ & -0.066 \\
Zn & $0.603^{\mathrm{b}}$ & 0.203 & 0.174 \\
\hline${ }^{\mathrm{a}}$ Extraction method: principal component analysis & \\
${ }^{\mathrm{b}}{ }^{\mathrm{b}}$ Loading values of being equal to or greater than 0.5 &
\end{tabular}

the variables. Therefore, the 8 variables from the surface sediments of the study area were summarised by three PCA/FA, with the cumulative percentage of $1.321 \%$, $14.682 \%$, and $64.646 \%$, respectively. These three components accounted for $2.034 \%, 22.596 \%$, and $49.965 \%$ of the variances as listed in Table 6. The resulting dendrogram of Q-mode hierarchical cluster analysis represents the grouping of samples according to the heavy metal. The dendrogram shows two different groups (i.e.) Cluster 1 $(9,10,11,12,13,14,15,16,17,18,19,20,21,22,23$ and 24), Cluster 2 (1, 2, 3, 4, 5, 6, 7, and 8) (Fig. 6).

\section{Discussion}

The spatial distribution of heavy metals in marine sediments is of great significance in elucidating the pollution summary of aquatic environments [55-57]. Besides that, those distributions of marine sediments is influenced by 


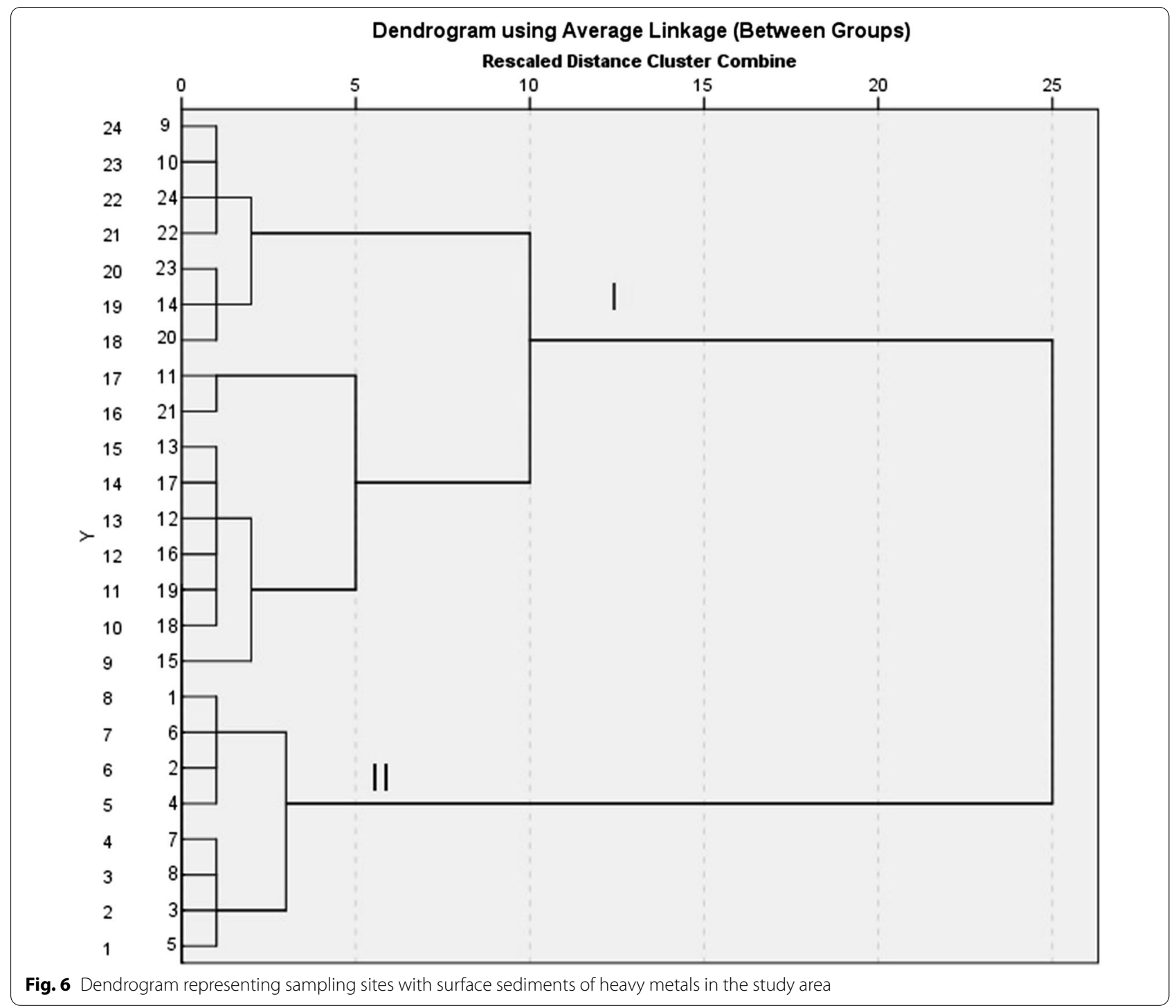

natural and anthropogenic factors such as weathering of parent rock, industrial wastewater, transportation, agriculture and environment (Morillo et al., 2004; El Nemr et al., 2006; Luo et al., 2006) The link between natural and anthropogenic influences on heavy metals in marine sediments is critical. Sediment analysis is crucial in determining the pollution status of the marine environment. The spatial distribution of the total metal concentration of $\mathrm{Fe}>\mathrm{Mn}>\mathrm{Cr}>\mathrm{Zn}>\mathrm{Cu}>\mathrm{Ni}>\mathrm{Pb}>\mathrm{Al}>\mathrm{Cd}$ is illustrated in Fig. 7. In general, the concentration of heavy metals in the sediments decreased in the following sequence: $\mathrm{Fe}>$ $\mathrm{Mn}>\mathrm{Cr}>\mathrm{Zn}>\mathrm{Cu}>\mathrm{Ni}>\mathrm{Pb}>\mathrm{Al}>\mathrm{Cd}$. The concentration of metals in the sediment were as follows: 42,516-62,413 $\mathrm{mg} \mathrm{kg}{ }^{-1}(\mathrm{Fe}), 425-896 \mathrm{mg} \mathrm{kg}{ }^{-1}(\mathrm{Mn}), 231-378 \mathrm{mg}$ $\mathrm{kg}^{-1}(\mathrm{Cr}), 214-298 \mathrm{mg} \mathrm{kg}^{-1}(\mathrm{Zn}), 31-84 \mathrm{mg} \mathrm{kg}^{-1}(\mathrm{Cu})$,
20.1-35.6 mg kg-1 $(\mathrm{Ni}), 10.2-19.5 \mathrm{mg} \mathrm{kg}^{-1}(\mathrm{~Pb}), 7.32-$ $15.4 \mathrm{mg} \mathrm{kg}^{-1}(\mathrm{Al})$, and $0.6-2.5 \mathrm{mg} \mathrm{kg}^{-1}(\mathrm{Cd})$.

The classification suggests that the muddy sand sediments observed in many stations were due to the poor wave action and shallow regions in the area [58]. The high value of $\mathrm{Fe}\left(62,413 \mathrm{mg} \mathrm{kg}^{-1}\right)$ was observed due to the convergence of ephemeral streams and the presence of rich mangrove ecosystems along the southern part of the study area at station 1 [59]. The red inorganic pigment used for painting boats is based on iron (III) oxide $\left(\mathrm{Fe}_{2} \mathrm{O}_{3}\right)$. Iron oxide leads to the co-precipitation of heavy metals which subsequently, increases the metal concentration in the sediment [60]. It is worth noting that the concentration of $\mathrm{Fe}$ in the east coast of India was higher than that of the study area due to chemical weathering. However, in this study, the maximum 


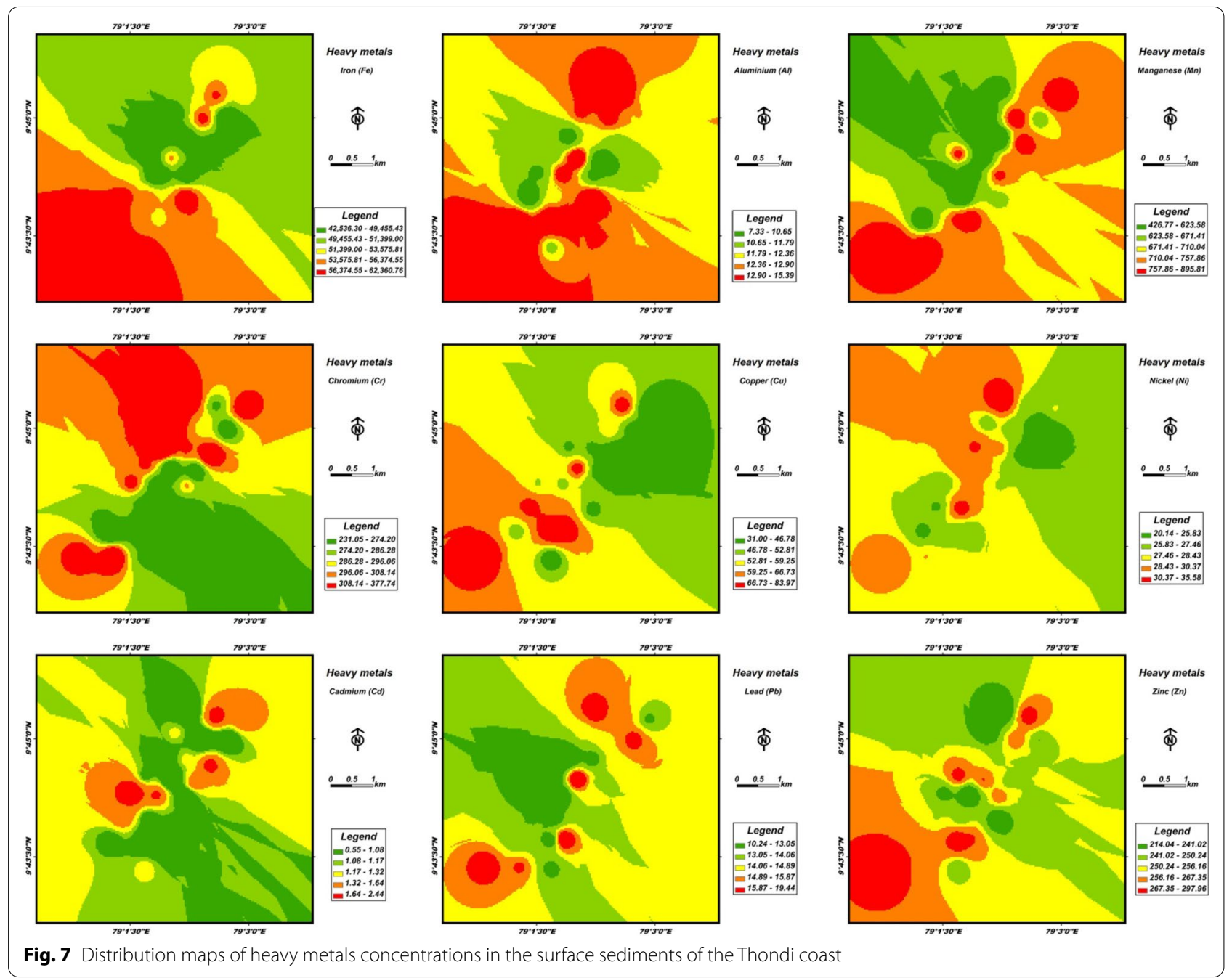

concentration of Fe was greater than the average crustal values [61]. The highest value of Mn $\left(896 \mathrm{mg} \mathrm{kg}^{-1}\right)$ was detected at station 1 due to the presence of mangrove vegetation along the coast. Overall, the concentrations of $\mathrm{Fe}$ and $\mathrm{Mn}$ indicate that both these elements are predominantly regulated by the riverine input and existence of the mangrove vegetation [20]. The main source of $\mathrm{Mn}$ is anthropogenic inputs such as industrial effluents and emissions [62]. The residual, $\mathrm{Fe} / \mathrm{Mn}$ oxide fractions are the dominant geochemical phases for heavy metals in these metal-enriched sediments (Fig. 8). For instance, the concentration of $\mathrm{Mn}$ in the Pitchavaram Mangrove region, east coast of India, was higher than that of the study area [63]. The concentration of Ni ranged from 20.1 to $35.6 \mathrm{mg} \mathrm{kg}^{-1}$ in the study area and it was mainly derived from the wind-blown dust, vegetation, and weathering of rocks and soils [17]. The concentration of $\mathrm{Ni}$ in the southeast coast of
India, however, was higher than that of the study area and the average crustal values [61]. The concentration of $\mathrm{Cr}$ ranged from 231 to $378 \mathrm{mg} \mathrm{kg}^{-1}$ and the average concentration of $\mathrm{Cr}$ in the sediment was $290.3 \mathrm{mg}$ $\mathrm{kg}^{-1}$. This value was higher than the average crustal value, thus indicating the input of $\mathrm{Cr}$ to the study area. Both natural and anthropogenic sources were responsible for the accumulation of $\mathrm{Cr}$ in the sediment. The values of $\mathrm{Cd}$ ranged from 0.6 to $2.5 \mathrm{mg} \mathrm{kg}^{-1}$ and the mean $\mathrm{Cd}$ concentration was higher $\left(1.2 \mathrm{mg} \mathrm{kg}^{-1}\right)$ than the average crustal value, thus indicating that the input of $\mathrm{Cd}$ was likely from both natural and anthropogenic sources, especially from the municipal sewage wastes nearby the study area. Nevertheless, it was previously reported that the concentration of $\mathrm{Cd}$ in the sediments was the main indicator of anthropogenic activity [61, 64]. Similarly due to anthropogenic inputs the concentration of $\mathrm{Cd}$ is $2.9 \mathrm{ppm}$ recorded in marine sediments 


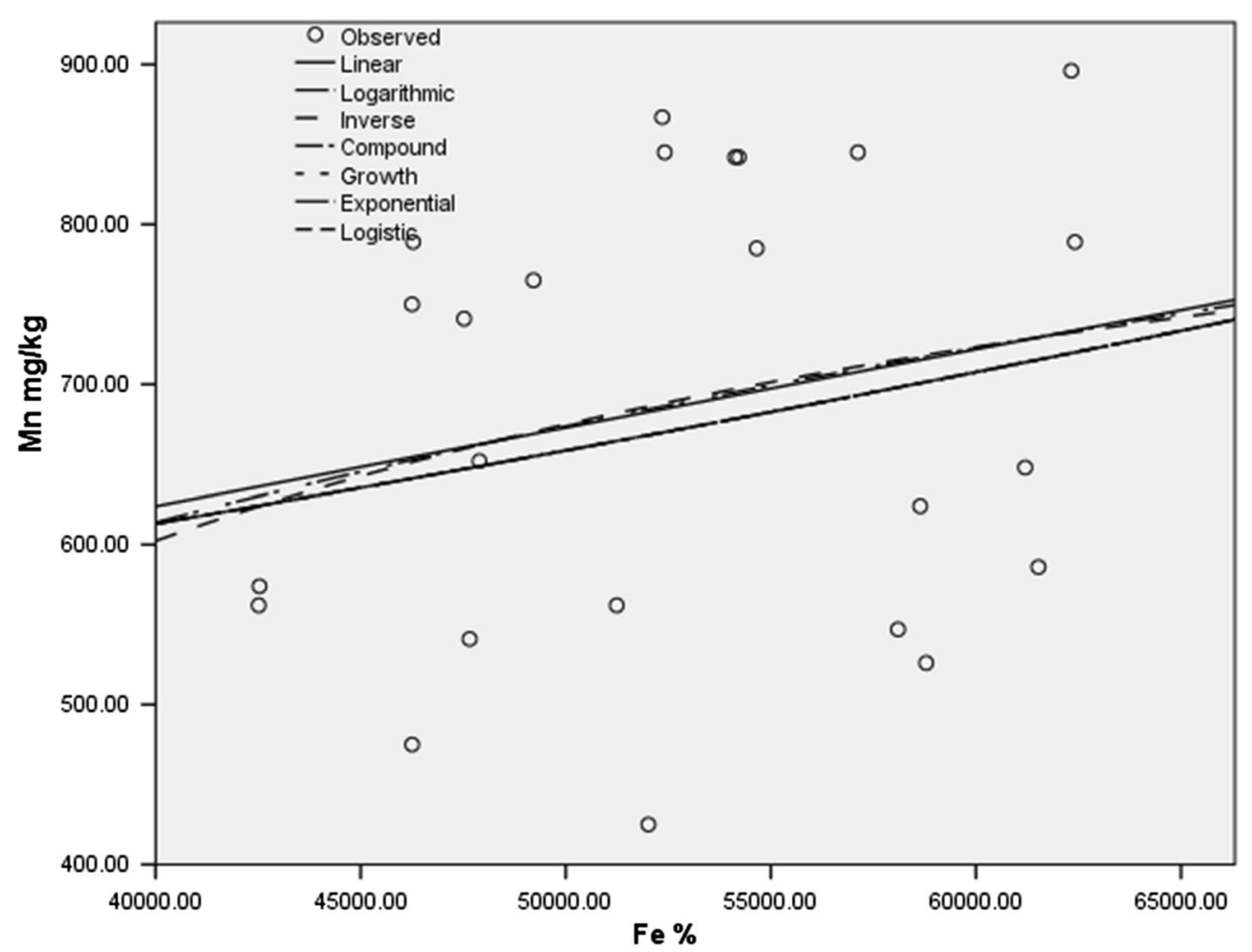

Fig. 8 Scatter plots of the linear regression models $(N=24)$ : Fe/ $\mathrm{Mn}\left(r^{2}=0.043\right)$

in the Gulf of Mannar and Palk Bay, southeast coast of India [65]. Municipal wastewater, for instance, has a higher concentration of $\mathrm{Cd}$, particularly from the fishing harbour activities, domestic sewage, oil, fish, and industrial and aquaculture wastes in the Ramnad District in Tamil Nadu. The concentration of $\mathrm{Zn}$ was observed to be higher at station $1\left(298 \mathrm{mg} \mathrm{kg}^{-1}\right)$ and lower at station $17\left(214 \mathrm{mg} \mathrm{kg}^{-1}\right)$. The anticorrosive paint used on the boat mainly consists of $\mathrm{ZnSO}_{4}[66$, 67]. Ocean currents and transportation activities erode this paint and increase the concentration of $\mathrm{Zn}$ in the shelf sediments. Additionally, emissions and effluents from the industries represent the main sources of zinc [62].

$\mathrm{Cu}$ was present in all the sediments and the values ranged from 31 to $84 \mathrm{mg} \mathrm{kg}^{-1}$, with an average concentration of $54.7 \mathrm{mg} \mathrm{kg}^{-1}$. The confluence point of the river was found to be rich in $\mathrm{Cu}$, thus indicating that the presence of trace elements in the marine environment was mainly due to the riverine runoff and drainage of untreated industrial wastes into the river. This inference was obtained from the low concentration of heavy metals and crustal average values detected in the nearby sampling areas. For instance, e-wastes such as waste from electroplating and printed circuit boards increased the levels of $\mathrm{Zn}, \mathrm{Pb}, \mathrm{Cu}, \mathrm{Cd}$, and $\mathrm{Hg}$ in the sediments collected from Hong Kong coastal areas [68]. Likewise, on the coast of Bangladesh, heavy metal contamination was mainly due to industrial pollutants [69]. The untreated effluents and solid wastes from many commercial and small-scale industries such fertilisers, sugar, paint, tobacco, jute, plastic, refinery, textiles, paper, and shipwreaking set up along the coastline and riverbank areas contributed to metal pollution [70-72]. Heavy metals such as $\mathrm{Ni}, \mathrm{Pb}, \mathrm{Zn}, \mathrm{Cu}$, and $\mathrm{Cr}$, derived from both natural and anthropogenic sources, are thought to be related to sedimentary phases such as organic matter and carbonate [73-75]. The heavy metal concentration in this study was compared with other coastal regions in India and other countries (Table 7). The heavy metal concentrations of $\mathrm{Cu}, \mathrm{Cr}, \mathrm{Zn}, \mathrm{Cd}$, and $\mathrm{Pb}$ in this study surpassed the crustal average and mean values of heavy metals in other coastal areas.

According to the classification [46], the majority of heavy metals showed minor to extremely severe enrichment in the sediments or displayed no enrichment to moderate enrichment. Based on the EF values, $65.63 \%$ of the samples belongs to no enrichment, $29.68 \%$ of the samples fall under minor enrichment followed by $6.25 \%$ of the samples categorised under moderately and 3.64\% 
Table 7 Comparison of heavy metal concentration and crustal average values obtained in this study with other coastal regions in India and around the world

\begin{tabular}{|c|c|c|c|c|c|c|c|c|}
\hline Study area & $\mathrm{Fe}$ & $\mathrm{Mn}$ & $\mathrm{Cu}$ & $\mathrm{Pb}$ & $\mathrm{Cd}$ & $\mathrm{Ni}$ & $\mathrm{Cr}$ & $\mathrm{Zn}$ \\
\hline Present study & 52,802 & 686.1 & 290.3 & 54.7 & 1.2 & 27.7 & 14.1 & 252.9 \\
\hline Average crustal [39] & 56,300 & 950 & 55 & 12.5 & 0.2 & 75 & 100 & 70 \\
\hline Coromandel Coast, Bay of Bengal [17] & 7,144 & - & 76.45 & 49.629 & 19.8 & 27.984 & 109.45 & 78.76 \\
\hline Southeast coast of India [92] & 2,780 & 543 & 6.7 & 19.7 & - & 50.7 & 191.3 & 58.7 \\
\hline Van Island, Gulf of Mannar, India [93] & 31,219 & 163 & 57.81 & 348.4 & - & 110.04 & 108.73 & 52.5 \\
\hline Koswari Island, Gulf of Mannar [18] & 30,988 & 147 & 54.2 & 496.7 & - & 92.7 & 67.5 & 16.9 \\
\hline Off Chennai, India [52] & 15,032 & - & 113.2 & 325 & - & 51.2 & 200.1 & 123.9 \\
\hline Cuddalore, SE coast of India [21] & 10,982 & 291 & 40 & 33.9 & - & 39.2 & 127 & 37.7 \\
\hline Palk Strait, southeast coast of India [94] & 55,680 & 661 & 69 & 19 & 0.4 & 27 & 302 & 244 \\
\hline Parangipettai coast, India [95] & 11,804 & 45 & 30.6 & 30.12 & - & 25.2 & 77.8 & 44.7 \\
\hline Arabian Gulf coast [96] & 4,100 & 120 & 18 & 12 & - & 6 & 130 & 46 \\
\hline Tuticorin Coast, India [97] & 28,717 & 330 & 52 & 42 & - & 30 & 15 & 247 \\
\hline South Port Klang, Malaysia [98] & - & 219.1 & 24.89 & 96.02 & 1.46 & 13.9 & 60.19 & 72.2 \\
\hline East Coast of India [23] & 85,800 & - & 140.14 & - & - & 81.76 & 133.22 & - \\
\hline Tuticorin Coast [24] & 28,717 & - & 52 & 42 & 0.2 & 75 & 15 & 247 \\
\hline Bay of Bengal, off Ennore [60] & 27,200 & - & 506.2 & 32.36 & 6.58 & 38.61 & 194.8 & 126.8 \\
\hline Southwest coast of Spain [99] & 35,300 & 569 & 336 & 197 & 2.5 & 50 & 92 & 649 \\
\hline Pitchavaram Mangrove region [63] & 32,482 & 941 & 43.4 & 11.2 & 6.6 & 62 & 141.2 & 93 \\
\hline
\end{tabular}

of the samples categorised under moderately severe in the study area. In the stations of $2,4,5,14,15,16$, and $19 \mathrm{EF}$ values for $\mathrm{Cd}$ showed moderately severe enrichment, thereby indicating that $\mathrm{Cd}$ was mainly derived from anthropogenic inputs. The higher concentration of $\mathrm{Cd}$ was mainly due to sewage discharge, mining agriculture, and industrial activities [17, 76-79]. Moreover, $\mathrm{Cd}$ is highly toxic to animals and plants and it has no proven essential biological function [80]. The overall enrichment of the elements in the marine sediments shows $\mathrm{Ni}>\mathrm{Mn}>\mathrm{Fe}>\mathrm{Cu}>\mathrm{Pb}>\mathrm{Cr}>\mathrm{Zn}>\mathrm{Cd}$. EF shows that the metal pollution occurred both from the natural and anthropogenic sources [81]. Both natural and anthropogenic sources are possible for the Cd contamination of samples around Thondi coast, Palk Bay, South India. Since all of the sites reported EF values greater than 5, the analysis concluded that anthropogenic inputs have resulted in substantial metal enrichment.

The ranking of RI for the heavy metals in the sediments was $\mathrm{Ni}<\mathrm{Cr}<\mathrm{Zn}<\mathrm{Cu}<\mathrm{Pb}<\mathrm{Cd}$. As previously mentioned, the major potential ecological risk of heavy metals in the surface sediment was from $\mathrm{Cd}$ and this observation was mainly due to the effects of anthropogenic activities such as the use of phosphate fertilisers and swine manure in irrigation [82].

Based on the values of $I_{\text {geo }}$, the sediments of Thondi coast are "extremely contaminated" with $\mathrm{Fe}, \mathrm{Mn}$, and $\mathrm{Cd}$, "strongly to extremely contaminated" for $\mathrm{Cr}$ and $\mathrm{Zn}$, "strongly contaminated" for $\mathrm{Ni}$ and $\mathrm{Cu}$, "moderately to strongly contaminated" for $\mathrm{Pb}$ possibly due to the anthropogenic inputs such as discharge of sewage, oil pollution from ships, use of paints for fishing and tourist boats. The high contents of $\mathrm{Fe}, \mathrm{Mn}$, and $\mathrm{Cd}$, in the study area result from various anthropogenic activities including dredge, land filling, localised oil pollution, using antifouling and anticorrosive paints from fishing and tourist boats, and sewage discharging from various sources within the study area. In similar that the recent bottom sediments of Mabahiss Bay, North Hurghada, Red Sea, Egypt [83].

The report by [84] indicated that the heavy metal, Cd, originates from agricultural soil contamination, municipal sewage waste, mining effluent, and sludges as well as from the erosion of phosporites, sulfide ores, hydrothermal mineralised rocks, and black shale deposits. In contrast, the values for $\mathrm{Fe}, \mathrm{Cr}, \mathrm{Mn}, \mathrm{Cu}, \mathrm{Pb}, \mathrm{Ni}$, and $\mathrm{Zn}$ were lower, thus indicating that there was no pollution based on the comparison with the worldwide sediment values. The difference in the indices, however, was due to the difference in the sensitivity of these indices in determining the pollutants in sediments [85]. The PLI values obtained for the sediments revealed that the sediments have been polluted by heavy metals. The values of both $\mathrm{mC}_{\mathrm{d}}$ and PLI suggest the effect of anthropogenic sources on the levels of heavy metal pollution in the sediments [40, 41, 86, 87]. The potential contamination index $\left(C_{\mathrm{p}}\right)$ values of $\mathrm{Fe}, \mathrm{Mn}, \mathrm{Ni}$, and $\mathrm{Pb}$ suggest a low level of contamination, while $\mathrm{Cu}$ and $\mathrm{Zn}$ indicated moderate contamination. In 
contrast, $\mathrm{Cr}$ and $\mathrm{Cd}$ showed a severe contamination level due to various sources such as domestic sewage, oil and fish, industrial, aquaculture waste, fishing harbour activities, and aquaculture waste in the study area.

The metals $\mathrm{Cd}, \mathrm{Cr}, \mathrm{Ni}, \mathrm{Cu}$, and $\mathrm{Pb}$ were significantly correlated as they were related to anthropogenic sewage and wastewater. The level of Fe indicated that the trace metal elements were acquired from their source [88], in which the same hydrogeochemical process redistributes these trace elements into the sediments [89]. Lastly, the significant and positive correlation observed for $\mathrm{Mn}$ with $\mathrm{Cr}, \mathrm{Ni}$, and $\mathrm{Cu}$ components substantiate their presence in the sediment [82-90]. It should be noted that $\mathrm{Cr}, \mathrm{Ni}, \mathrm{Cu}$, and $\mathrm{Pb}$ are extensively recognised to have anthropogenic activities, whereby $\mathrm{Cu}, \mathrm{Pb}$, and $\mathrm{Ni}$ are commonly derived from anthropogenic sewage and wastewater, while $\mathrm{Cr}$ is generally associated with industrial activities in the area [91]. The first cluster of the sampling sites $9,10,11,12$, $13,14,15,16,17,18,19,20,21,22,23$ and 24 with significant contamination the background sites. Cluster 2 includes three sub-clusters of the sampling sites 1, 2, 3, 4, $5,6,7$, and 8 with moderate enrichment of heavy metals.

\section{Principal component analysis/factor analysis}

The PCA/FA, which corresponded to three eigenvalues were greater than 1 . The three PCA/FA accounted for $74.60 \%$ of the total variance in the data and displayed the different factors (sources) influencing sediment pollution in the study region. Table 6 shows that PC1 accounted for $2.034 \%$ of the total variance, and $\mathrm{Cd}$ and $\mathrm{Zn}$ contributed to the strong positive loadings. The results for EF (moderately severe enrichment), CF (considerable contamination), $C_{\mathrm{p}}$ (severe contamination level), $I_{\text {geo }}$ (extreme contamination) and RI (very high ecological risk) suggest that the presence of $\mathrm{Cd}$ (0.568) was due to high anthropogenic inputs (81). The $\mathrm{CF}$ (considerable contamination for $\mathrm{Zn}$ ), $C_{\mathrm{p}}$ (moderate contamination for $\mathrm{Zn}$ ), and RI (considerable ecological risk for $\mathrm{Zn}$ ) values suggest that $\mathrm{Zn}(0.603)$ is influenced by anthropogenic sources. Therefore, it is assumed that $\mathrm{PC} 1$ primarily represents the contribution of pollutants by anthropogenic sources. The high positive loadings of $\mathrm{Cd}(0.568)$, and $\mathrm{Zn}(0.603)$ in the PC1 indicate that these metals may have a similar distribution and common anthropogenic sources in the study area. Similarly, from the PCA results the presence of $\mathrm{Cd}$, and $\mathrm{Zn}$ pollutants signifies the anthropogenic contamination in the Indian Sunderban [100]. In PC2 (22.596\% of the total variance), $\mathrm{Fe}, \mathrm{Mn}$, and $\mathrm{Pb}$ contributed to the strong positive loadings. The results for EF (no enrichment for $\mathrm{Pb}$, low level of contamination for $\mathrm{Fe}$, and $\mathrm{Mn}$ ), $I_{\text {geo }}$ (extremely contaminated for Fe, $\mathrm{Mn}$ and moderately to strongly contaminated for $\mathrm{Pb}$ ), and
RI (considerable ecological risk for $\mathrm{Pb}$ ) suggest that levels of $\mathrm{Fe}, \mathrm{Mn}$, and $\mathrm{Pb}$ are influenced by low levels of pollutants. Therefore, it can be assumed that PC2 primarily represents contaminants of low anthropogenic sources. For PC3 (49.965\% of the total variance), a strong positive loading was observed for $\mathrm{Cr}, \mathrm{Cu}$, and $\mathrm{Ni}$. The results for $\mathrm{EF}$ (minor enrichment for $\mathrm{Cr}$, no enrichment for $\mathrm{Cu}$ and $\mathrm{Ni}$ ), CF (moderately contaminated for $\mathrm{Cr}$, low level of contamination for $\mathrm{Cu}$ and $\mathrm{Ni}$ ), $I_{\text {geo }}$ (strongly to extremely contaminated" for $\mathrm{Cr}$, strongly contaminated" for $\mathrm{Ni}$ and $\mathrm{Cu}$ ), and RI (considerable ecological risk for $\mathrm{Cu}$, moderate ecological risk for $\mathrm{Ni}$ and $\mathrm{Cr}$ ) suggest that levels of $\mathrm{Cr}, \mathrm{Cu}$, and $\mathrm{Ni}$ are influenced by low levels of pollutants. Therefore, it can be assumed that PC3 primarily represents contaminants of low anthropogenic sources. From the PCA results, it can be concluded that factors 1 and 3 are from anthropogenic sources such as domestic sewage, waste water discharge, construction activities and urban runoff.

\section{Conclusion}

The evaluation of heavy metals in the surface sediments along the Thondi coast in Palk Bay was undertaken, whereby sand, mud, organic matter, and heavy metals such as $\mathrm{Fe}, \mathrm{Al}, \mathrm{Mn}, \mathrm{Cr}, \mathrm{Cu}, \mathrm{Ni}, \mathrm{Cd}, \mathrm{Pb}$, and $\mathrm{Zn}$ were analysed. The mean concentration of heavy metals was shown to decrease in the following order: $\mathrm{Fe}>\mathrm{Mn}$ $>\mathrm{Cr}>\mathrm{Zn}>\mathrm{Cu}>\mathrm{Ni}>\mathrm{Pb}>\mathrm{As}>\mathrm{Cd}$. The sedimentary texture observed in most of the stations was muddy sand due to the shallow depth and poor wave action in the study area. The pollution indices such as $\mathrm{EF}, \mathrm{CF}, \mathrm{m} C_{\mathrm{d}}$, $\mathrm{CI}, \mathrm{E}_{\mathrm{r}}^{\mathrm{i}}, I_{\text {geo }}$, and RI indicated that $\mathrm{Cd}$ was responsible for the high contamination level in the study area except for $I_{\text {geo }}$. The PCA results also confirmed that $\mathrm{Cd}$ had a high contamination level, as indicated by the strong positive loadings. The main source of $\mathrm{Cd}$ was due to anthropogenic inputs such as municipal wastewater, domestic sewage discharge, fishing harbour activities, and industrial and aquaculture wastes. Based on the results obtained for EF, CF, $\mathrm{m} C_{\mathrm{d}}, \mathrm{CI}, \mathrm{E}_{\mathrm{r}}^{\mathrm{i}}$, and RI, it was found that the presence of heavy metals such as $\mathrm{Cu}, \mathrm{Zn}, \mathrm{Pb}$, and $\mathrm{Cr}$ led to moderate contamination in the study area. The PLI results suggest that the sediments in the study area were polluted by heavy metals. The findings of this study revealed that the study area frequently receives heavy metal contaminants from different sources and if the concentration of these heavy metals continues to increase, the toxicity will also increase, thus affecting the entire food chain within the marine ecosystem. Therefore, to protect the marine ecosystem, illegal discharges into the marine environment should be properly monitored and effluents from the industries, municipal, 
and domestic areas should be pretreated before its discharge into the coastal areas.

\section{Acknowledgements}

The authors are grateful and thank the Head of the Department, School of Marie Sciences, Department of Oceanography and Coastal Area Studies,

Alagappa University, Karaikudi- 630003.

\section{Authors' contributions}

Karthikeyan Perumal: conceptualisation, supervision, investigation, methodology, writing —original draft, writing — review and editing. Joseph Antony: data curation, formal analysis; Subagunasekar M: software; data analysis; investigation.

\section{Funding}

No funding.

\section{Availability of data and materials}

http://dx.doi.org/10.17632/66fvpkww3r.2

\section{Declarations}

Ethics approval and consent to participate

Not applicable.

\section{Consent for publication}

Not applicable.

\section{Competing interests}

The authors declare that they have no competing interests.

\section{Author details}

${ }^{1}$ School of Marine Sciences, Department of Oceanography and CoastalArea Studies, Alagappa University, Karaikudi, Tamil Nadu 630 003, India. ${ }^{2}$ Department of Civil Engineering, Saveetha School of Engineering, Saveetha Institute of Medical \& Technical Sciences, Chennai, Tamil Nadu 602105, India.

\section{Received: 31 December 2020 Accepted: 4 May 2021}

Published online: 19 May 2021

\section{References}

1. Demirak A, Yilmaz F, Tuna AL, Ozdemir N (2006) Heavy metals in water, sediment and tissues of Leuciscus cephalus from a stream in southwestern Turkey. Chemosphere 63:1451-1458. https://doi.org/10.1016/j. chemosphere.2005.09.033

2. Khaled A, Nemr AE, Sikaily AE (2006) An assessment of heavy metal contamination in surface sediments of the Suez Gulf using geoaccumulation indexes and statistical analysis. Chem Ecol 22:239-252. https://doi.org/10.1080/02757540600658765

3. Singh KP, Mohan D, Singh VK, Malik A (2005) Studies on distribution and fractionation of heavy metals in Gomti river sediments-a tributary of the Ganges. J Hydrol 312:14-27. https://doi.org/10.1007/ s10661-005-6395-6

4. Ghrefat $\mathrm{H}$, Yusuf N (2006) Assessing Mn, Fe, Cu, Zn, and Cd pollution in bottom sediments of Wadi Al-Arab Dam Jordan. Chemosphere 65:2114-2121. https://doi.org/10.1016/j.chemosphere.2006.06.043

5. Naser HA (2013) Assessment and management of heavy metal pollution in the marine environment of the Arabian Gulf: A review. Mar Pollut Bull 72:6-13. https://doi.org/10.1016/j.marpolbul.2013.04.030

6. Ozkan EY, Buyukisik B (2012) Geochemical and statistical approach for assessing heavy metal accumulation in the southern Black Sea sediments. Ekoloji 21(83):11-24. https://doi.org/10.5053/ekoloji.2012.832

7. Wang WX, Rainbow PS (2008) Comparative approaches to understand metal bioaccumulation in aquatic animals. Comp Biochem Physiol Part C Toxicol Pharmacol 148:315-323. https://doi.org/10.1016/j.cbpc.2008. 04.003
8. DeForest D, Brix K, Adams W (2007) Assessing metal bioaccumulation in aquatic environments: The inverse relationship between bioaccumulation factors, trophic transfer factors and exposure concentration. Aquat Toxicol 84:236-246. https://doi.org/10.1016/j.aquatox.2007.02.022

9. Jarup $L$ (2003) Hazards of heavy metal contamination. Braz Med Bull 68:425-462. https://doi.org/10.1093/bmb/ldg032

10. Paneer Selvam A, Laxmi Priya S, Kakolee B, Hariharan G, Purvaja R, Ramesh R (2012) Heavy metal assessment using geochemical and statistical tools in the surface sediments of Vembanad Lake, southwest coast of India. Environ Monit Assess. 184:5899-5915. https://doi.org/10. 1007/s10661-011-2389-8

11. Ratheesh CS, Joseph MM, Gireesh TR, Renjith KR, Manju M, Chandramohanakumar N (2010) Spatial variability and contamination of heavy Metals in the inter-tidal systems of a tropical environment. Int J Environ Res. 4(4):691-700. https://doi.org/10.22059/IJER.2010.255

12. Harikumar PS, Nasiru P, Mujeeburahmanm P (2009) Distribution of heavy metals in the core sediments of a tropical wetland system. Int J Environ Sci Te 6(2):225-232

13. Carral E, Villares R, Puente X, Carballeira A (1995) Influence of watershed lithology on heavy metal levels in estuarine sediments and organisms in Galicia (north-west Spain). Mar Pollut Bull 30:604-608. https://doi.org/10.1016/0025-326X(95)00017-H

14. Pande N, Nayak GN (2013) Understanding distribution and abundance of metals with space and time in estuarine mudflat sedimentary environment. Environ Earth Sci 70:2561-2575. https://doi.org/10. 1007/s12665-013-2298-y

15. Jayaraju N, Sundara Raja Reddy BC, Reddy KR (2009) Metal pollution in coarse sediments of Tuticorin coast, Southeast coast of India. Environ Geol 56:1205-1209. https://doi.org/10.1007/s00254-008-1220-5

16. Fatoki OS, Mathabatha S (2001) An assessment of heavy metal pollution in the East London and Port Elizabeth harbours. Water SA 27(2):233-240. https://doi.org/10.4314/wsa.v27i2.4997

17. Anbuselvan N, Senthil Nathan D, Sridharan M (2018) Heavy metal assessment in surface sediments off Coromandel Coast of India: Implication on marine pollution. Mar Pollut Bull. 131:712-726. https://doi.org/10.1016/j.marpolbul.2018.04.074

18. Krishnakumar S, Ramasamy S, Chandrasekar N, Simon Peter T, Gopal V, Godson PS, Magesh NS (2017) Trace element concentrations in reef associated sediments of Koswari Island, Gulf of Mannar biosphere reserve, southeast coast of India. Mar Pollut Bull 117:515-522. https:// doi.org/10.1016/j.marpolbul.2017.02.016

19. Magesh NS, Chandrasekar N, Krishnakumar S, Simon PT (2017) Trace element contamination in the nearshore sediments of the Tamiraparani estuary, Southeast coast of India. Mar Pollut Bull 116(2017):508516. https://doi.org/10.1016/j.marpolbul.2017.01.005

20. Kasilingam K, Suresh Gandhi M, Krishnakumar S, Magesh NS (2016) Trace element concentration in surface sediments of Palk Strait, southeast coast of Tamil Nadu. India Mar Pollut Bull 111:500-508. https://doi.org/10.1016/j.marpolbul.2016.06.051

21. Jayaprakash M, Gopal V, Anandasabari K, Kalaivanan R, Sujitha SB, Jonathan MP (2016) Enrichment and toxicity of trace metals in nearshore bottom sediments of Cuddalore, SE coast of India. Environ Earth Sci 75:1303. https://doi.org/10.1007/s12665-016-6082-7

22. Solai A, Suresh Gandhi M, Kasilingam K, Sriraman E (2013) Heavy Metal Accumulation in the Surface Sediments off Pondicherry, Bay of Bengal, South East Coast of India. Int J Innov Res in Sci Eng Tech. 2:10

23. Alagarsamy R, Zhang J (2010) Geochemical characterization of major and trace elements in the coastal sediments of India. Environ Monit Assess 161:161-176. https://doi.org/10.1007/s10661-008-07352

24. Jayaraju N, Sundara Raja RBC, Reddy KR (2009) Metal pollution in coarse sediments of Tuticorin coast. Southeast coast of India Environ Geol 56:1205-1209. https://doi.org/10.1007/s00254-008-1220-5

25. Jayaprakash M, Jonathan MP, Srinivasalu S, Muthuraj S, Ram-Mohan V, Rajeshwara-Rao N, (2008). Acid-leachable trace metals in sediments from an industrialized region (Ennore Creek) of Chennai City, SE coast of India: an approach towards regular monitoring. Estuar Coast Shelf Sci. 76 (2008), 692e703. https://doi.org/https://doi.org/10.1016/j.ecss. 2007.07.035

26. Jonathan MP, Ram-Mohan V, Srinivasalu S (2004) Geochemical variations of major and trace elements in recent sediments, off the Gulf of 
Mannar, southeast coast of India. Environ Geol 45:466-480. https:// doi.org/10.1007/s00254-003-0898-7

27. Selvaraj K, Ram Mohan V, Jonathan MP, Siddartha R, Srinivasalu S (2003) Distribution of nondetrital trace metals in sediment cores from Ennore Creek, Southeast coast of India. J Geol Soc India 62:191-204

28. Achyuthan H, Richardmohan D, Srinivasalu S, Selvaraj K (2002) Trace metals in the sediment cores of estuary and tidal zones from northern part of southeast coast of India. Indian J Mar Sci 31:141-149

29. Folk RL (1954) The distinction between grain size and mineral composition in sedimentary-rock nomenclature. J Geol 62(4):344-359

30. Pejrup M (1988) The triangular diagram used for classification of estuarine sediments: a new approach. In: de Boer PL, Van Gelder A, Nio SD (eds) Tide-influenced Sedimentary Environments and Facies. Reidel, Dordrecht, pp 289-300

31. Fleming BW (2000) A revised textural classification of gravel-free muddy sediments on the basis of ternary diagrams. Cont Shelf Res. 20:11251137. https://doi.org/10.1016/S0278-4343(00)00015-7

32. US EPA. (1996). Guidance on Use of Modeled Results to Demonstrate Attainment of the Ozone NAAQS, EPA-454/B-95-007

33. Naifar I, Pereira F, Zmemla R, Bouaziz M, Elleuch B, Garcia D (2018) Spatial distribution and contamination assessment of heavy metals in marine sediments of the southern coast of Sfax, Gabes Gulf, Tunisia. Mar Pollut Bull 131:53-62. https://doi.org/10.1016/j.marpolbul.2018.03.048

34. Din ZB (1992) Use of aluminium to normalize heavy-metal data from estuarine and coastal sediments of Straits of Melaka. Mar Pollut Bull 24(10):484-491. https://doi.org/10.1016/0025326x(92)90472-i

35. Choi KY, Kim SH, Hong GH, Chon HT (2011) Distributions of heavy metals in the sediments of South Korean harbors. Environ Geochem Health 34(S1):71-82. https://doi.org/10.1007/s10653-011-9413-3

36. Sakan S, Devic G, Relic D, Andelkovic I, Sakan N, Dordevic D (2014) Evaluation of sediment contamination with heavy metals: the importance of determining appropriate background content and suitable element for normalization. Environ Geochem Health 37(1):97-113. https://doi. org/10.1007/s10653-014-9633-4

37. Muller $G$ (1981) The heavy metal pollution of the sediments of the Neckar and its tributaries. Chem Ztg 6:64-157

38. Ergin M, Saydam C, Basturk O, Erdem E, Yoruk R (1991) Heavy metal concentrations in surface sediments from the two coastal inlets (Golden Horn Estuary and Izmit Bay) of the North-eastern Sea of Marmara. Chem Geol 91:269-285. https://doi.org/10.1016/0009-2541(91)90004-B

39. Taylor SR, McLennan SM (1995) The geochemical evolution of the continental crust. Rev Geophys 33(2):241. https://doi.org/10.1029/95rg00262

40. Hakanson L (1980) An ecological risk index for aquatic pollution control: a sedimentological approach. Water Res 14:975-1001. https://doi.org/ 10.1016/0043-1354(80)90143-8

41. Abrahim GM, Parker RJ (2008) Assessment of heavy metal enrichment factors and the degree of contamination in marine sediments from Tamaki Estuary, Auckland New Zealand. Environ Monit Assess 136:227-238. https://doi.org/10.1007/s10661-007-9678-2

42. Tomlinson DL, Wilson JG, Harris CR, Jeffrey DW (1980) Problems in the assessment of heavy metal levels in estuaries and the formation of a pollution index. Helgol Meeresunters 33:566-575

43. Ogbeibu AE, Omoigberale MO, Ezenwa IM, Eziza JO, Igwe JO (2014) Using pollution load index and geoaccumulation index for the assessment of heavy metal pollution and sediment quality of the Benin River Nigeria. Natural Environ 2(1):1-9

44. Forstner U, AhlfW, Calmano W, Kersten M. (1990). Sediment Criteria Development. In: Sediments and Environmental Geochemistry, Heling, D., P. Rothe, U. Forstner and P. Stoffers (Eds.). Springer Verlag, Berlin, New Yark

45. Muller G (1979) Heavy metals in the sediment of the Rhine-Changes seity. Umschau in Wissenschaft und Technik 79:778-783

46. Muller $\mathrm{G}$ (1969) Index of geoaccumulation in sediments of the Rhine River. Geo J 2:108-118

47. Dauvalter $V$, Rognerud S (2001) Heavy metal assessment in sediments of the Pasvik River drainage. Chemosphere 42:9-18. https://doi.org/10. 1016/s0045-6535(00)00094-1

48. Chandramohan J, Chandrasekaran A, Senthilkumar G, Elango G, Ravisankar R (2016) Heavy metal assessment in sediment samples collected from pattipulam to Dhevanampattinam along the east coast of Tamilnadu using EDXRF Technique. J Heavy Metal Toxi Disea 1:1-9

49. Godson PS, Magesh NS, Peter TS, Chandrasekar N, Krishnakumar S, Vincent SGT (2018) A baseline study on the concentration of trace elements in the surface sediments off Southwest coast of Tamil Nadu India. Mar Pollut Bull 126:381-388. https://doi.org/10.1016/j.marpolbul. 2017.11.027

50. Karthikeyan P, Vennila G, Venkatachalapathy R, Subramani T, Prakash R, Aswini MK (2018) Assessment of heavy metals in the surface sediments of the Emerald Lake using of spatial distribution and multivariate techniques. Environ Monit Assess. 22(11):668. https://doi.org/10.1007/ s10661-018-7037-0

51. Kalaivanan R, Jayaprakash M, Nethaji S, Arya V, Giridharan L (2017) Geochemistry of Core Sediments from Tropical Mangrove Region of Tamil Nadu: Implications on Trace Metals. J Earth Sci Clim Change. https://doi. org/10.4172/2157-7617.1000385

52. Gopal V, Krishnakumar S, Simon Peter T, Nethaji S, Suresh Kumar K, Jayaprakash M, Magesh NS (2016) Assessment of trace element accumulation in surface sediments off Chennai coast after a major flood event. Mar Pollut Bull 114(2):1063-1071. https://doi.org/10.1016/j. marpolbul.2016.10.019

53. Singh KP, Malik A, Mohan D, Sinha S (2004) Multivariate statistical techniques for the evaluation of spatial and temporal variations in water quality of Gomti River (India), a case study. Water Res 38:3980-3992

54. Shrestha S, Kazama F (2007) Assessment of surface water quality using multivariate statistical techniques, a case study of the Fuji river basin Japan. Environ Modell Softw 22:464-475

55. Rubio B, Pye K, Rae JE, Rey D (2001) Sedimentological characteristics, heavy metal distribution and magnetic properties in subtidal sediments, Ria de Pontevedra, NW Spain. Sedimentology 48:1277-1296

56. Birch GF, Taylor SE, Matthai C (2001) Small-scale spatial and temporal variance in the concentration of heavy metals in aquatic sediments: a review and some new concepts. Environ Pollut 113:357-372

57. Liu WX, Li XD, Shen ZG, Wang DC, Wai OWH, Li YS (2003) Multivariate statistical study of heavy metal enrichment in sediments of the Pearl River Estuary. Environ Pollut 121:377-388

58. Shepard FP (1954) Nomenclature based on sand-silt-clay ratios. J Sediment Resear 24:151-158. https://doi.org/10.1306/D4269774-2B2611D7-8648000102C1865D

59. Sundararajan M, Natesan U (2010) Geochemistry of core sediments from Mullipallam creek, South East coast of India. Environ Earth Sci 61(5):947-961. https://doi.org/10.1007/s12665-009-0414-9

60. Muthu Raj S, Jayaprakash M (2008) Distribution and enrichment of trace metals in marine sediments of Bay of Bengal, off Ennore, southeast coast of India. Environ Geol 56:207-217. https://doi.org/10.1007/ s00254-007-1156-1

61. Taylor SR (1964) Abundance of Chemical Elements in the Continental Crust: A New Table. Geochim Cosmochim Acta 28:1273-1285. https:// doi.org/10.1016/0016-7037(64)90129-2

62. Kelin LA, Long M, Nash N, Kirschner S (1974) Sources of metals in New York City waste water. J Water Poll Control 46:2653-2662

63. Ramanathan AL, Subramanian V, Ramesh R, Chidambaram S, James A (1999) Environmental geochemistry of the Pitchavaram mangrove ecosystem (tropical). Southeast coast of India Environ Geol 37(3):223-233. https://doi.org/10.1007/s002540050380

64. Shen GT, Boyle EA (1988) Determination of lead, cadmium and other trace metals in annually-banded corals. Chem Geol 97:47-62. https:// doi.org/10.1016/0009-2541(88)90005-8

65. Palanichamy S, Rajendran A (2000) Heavy metal concentrations in sea water and sediments of Gulf of Mannar and Palk Bay, southeast coast of India. Indian J Mar Sci 29:116-119

66. Lin YP, Teng TP, Chang TK (2002) Multivariate analysis of soil heavy metals pollution and landscape pattern in Changhua county in Taiwan. Landsc Urban Plan 62:19-35

67. Yasar D, Aksu AE, Uslu O (2001) Anthropogenic pollution in Izmit Bay: heavy metal concentrations in surface sediments. Turkish J Eng Env Sci 25:299-313

68. Wang SL, Xu XR, Sun YX, Liu JL, Li HB (2013) Heavy metal pollution in coastal areas of South China: a review. Mar Pollut Bull. 76(1-2):7-15. https://doi.org/10.1016/..marpolbul.2013.08.025 
69. Sharifuzzaman SM, Rahman H, Ashekuzzaman SM, Islam MM, Chowdhury SRS, Hossain HM. (2016). Heavy Metals Accumulation in Coastal Sediments, Hasegawa et al. (eds.), Environmental Remediation Technologies for Metal Contaminated Soils. https://doi.org/10.1007/ 978-4-431-55759-3_2, 21-42

70. Rasul MG, Faisal I, Khan MMK (2006) Environmental pollution generated from process industries in Bangladesh. Int J Environ Pollut. 28:144-161. https://doi.org/10.1504/IJEP.2006.010881

71. Kashem MA, Singh BR (1999) Heavy metal contamination of soil and vegetation in the vicinity of industries in Bangladesh. Wat Air Soil Pollut 115:347-361

72. Islam KL, Hossain MM (1986) Effect of ship scrapping on the soil and sea environment in the coastal area of Chittagong. Bangladesh Mar Pollut Bull 17:462-463. https://doi.org/10.1016/0025-326X(86)90836-2

73. Chakraborty P, Babu PV (2015) Environmental controls on the speciation and distribution of mercury in surface sediments of a tropical estuary India. Mar Pollut Bull 95(1):350-357. https://doi.org/10.1016/j. marpolbul.2015.02.035

74. Tessier A, Campbell PGC, Bisson M (1979) Sequential extraction procedure for the speciation of particulate trace metals. Anal Chem 51:844-851

75. Goldberg ED (1954) Marine geochemistry 1. Chemical scavengers of the sea. J Geol. 1:249-265

76. Karthikeyan P, Vennila G, Nanthakumar G, Aswini M (2020) Dataset for spatial distribution and pollution indices of heavy metals in the surface sediments of Emerald Lake, Tamil Nadu India. Data Brief 28:104877. https://doi.org/10.1016/j.dib.2019.104877

77. Zhang WF, Ma WQ, Ji YX, Fan MS, Oenema O, Zhang FS (2008) Efficiency, economics, and environmental implications of phosphorus resource use and the fertilizer industry in China. Nutr Cycling Agroecosyst 80(2):131-144. https://doi.org/10.1007/s10705-007-9126-2

78. Ranjan RK, Ramanathan AL, Singh G, Chidambaram S (2008) Assessment of metal enrichments in tsunamigenic sediments of Pichavaram mangroves, southeast coast of India. Environ Monit Assess 147:389411. https://doi.org/10.1007/s10661-007-0128-y

79. Srikanth R, Madhumohan Rao A, Shravan Kumar CH, Khanum A (1993) Lead, cadmium, nickel, and zinc contamination of ground water around Hussain Sagar Lake, Hyderabad India. Bull Environ Contam Toxicol 50:138-143. https://doi.org/10.1007/BF00196552

80. Alloway BJ (1990) Heavy metals in soils. Wiley, New York

81. Youssef M, Madkour H, El-Attar R, Mansour A, Badawi A (2020) Assessment of metal contamination in coastal marine sediments of Makadi Bay on the Red Sea Egypt. Marine Freshw Res. https://doi.org/10.1071/mf19306

82. Rodríguez Martín JA, Ramos-Miras JJ, Boluda R (2013) Spatial relations of heavy metals in arable and greenhouse soils of a Mediterranean environment region (Spain). Geoderma 200-201:180-188. https://doi. org/10.1016/j.geoderma.2013.02.014

83. Attia OE, Ghrefat $\mathrm{H}$ (2013) Assessing heavy metal pollution in the recent bottom sediments of Mabahiss Bay, North Hurghada, Red Sea, Egypt. Environ Monit Assessment 185(12):9925-9934. https://doi.org/10.1007/ S10661-013-3302-4

84. GESAMP (Joint Group of Experts on Scientific Aspects of Marine Pollution) (1985). Atmospheric transport of contaminants into the Mediterranean region. Reports and Studies GESAMP 26. World Meteorological Organisation

85. Praveena SM, Ahmed A, Radojevic M, Abdullah MH, Aris AZ (2007) Factor-cluster analysis and enrichment study of mangrove sediments-an example from Mengkabong. Sabah Malaysian J Anal Sci 11(2):421-430

86. Cheng Q, Wang R, Huang W, Wang W, Li X (2015) Assessment of heavy metal contamination in the sediments from the Yellow River Wetland National Nature Reserve (the Sanmenxia section). China. Environ Sci Pollut Res. 22(11):8586-8593. https://doi.org/10.1007/ s11356-014-4041-y
87. Varol M (2011) Assessment of heavy metal contamination in sediments of the Tigris River (Turkey) using pollution indices and multivariate statistical techniques. J Hazard Mater 195:355-364. https://doi.org/10. 1016/j.jhazmat.2011.08.051

88. Bhuiyan MA, Parver L, Isalm MA, Dampare SB, Suzuki S (2009) Heavy metal pollution of coal mine affected agricultural soils in the northern part of Bangladesh. J Hazard Mater. 173:384-392. https://doi.org/10. 1016/j.jhazmat.2009.08.085

89. Bai J, Xiao R, Cui B, Zhang K, Wang Q, Liu X (2011) Assessment of heavy metal pollution in wetland soils from the young and old reclaimed regions in the Pearl River estuary South China. Environ Pollut. 159:817824. https://doi.org/10.1016/j.envpol.2010.11.004

90. Fianko JR, Laar C, Osei J, Anim AK, Gibrilla A, Adomako D (2013) Evaluation of some heavy metal loading in the Kpeshi lagoon Ghana. Appl Water Sci 3:311-319. https://doi.org/10.1007/s13201-013-0083-4

91. Li LY, Hall KY, Yuan G, Mattu D, McCallum CM (2009) Mobility and bioavailability of trace metals in the water-sediment system of the highly urbanized brunette watershed. Water Air Soil Pollut 197:249-266. https://doi.org/10.1007/s11270-008-9808-7

92. Kumar SB, Padhi RK, Mohanty AK, Satpathy KK (2017) Elemental distribution and trace metal contamination in the surface sediment of south east coast of India. Mar Pollut Bull. 114(2):1164-1170. https://doi.org/10. 1016/j.marpolbul.2016.10.038

93. Krishnakumar S, Ramasamy S, Chandrasekar N, Peter TS, Godson PS, Gopal V, Magesh NS (2017) Spatial risk assessment and trace element concentration in reef associated sediments of Van Island, southern part of the Gulf of Mannar India. Mar Pollut Bull. 115(1-2):444-450. https:// doi.org/10.1016/j.marpolbul.2016.10.067

94. Kasilingam K, Suresh Gandhi M, Krishnakumar S, Magesh NS (2016) Trace element concentration in surface sediments of Palk Strait, southeast coast of Tamil Nadu India. Mar Pollut Bull. 111(1-2):500-508. https://doi.org/10.1016/j.marpolbul.2016.06.051

95. Sundaramanickam A, Shanmugam N, Cholan S, Kumaresan S, Madeswaran P, Balasubramanian T (2016) Spatial variability of heavy metals in estuarine, mangrove and coastal ecosystems along Parangipettai Southeast coast of India. Environ Pollut. 218:186-195. https://doi. org/10.1016/j.envpol.2016.07.048

96. Fahad IA, Adel RU, Abdullah SAF (2014) Heavy metals in the soils of the Arabian Gulf coast affected by industrial activities: analysis and assessment using enrichment factor and multivariate analysis. Arab J Geosci. https://doi.org/10.1007/s12517-014-1298-x

97. Magesh NS, Chandrasekar N, Krishna Kumar S, Glory M (2013) Trace element contamination in the estuarine sediments along coast-Gulf of Mannar, southeast coast of India. Mar Pollut Bull 73:355-361. https:// doi.org/10.1016/j.marpolbul.2013.05.041

98. Sany TSB, Salleh A, Rezayi M, Saadati N, Narimany L, Tehrani GM (2013) Distribution and contamination of heavy metal in the coastal sediments of Port Klang, Selangor Malaysia. Water Air Soil Pollut 224:1476. https://doi.org/10.1007/s11270-013-1476-6

99. Morillo J, Usero J, Gracia I (2004) Heavy metal distribution in marine sediments from the southwest coast of Spain. Chemosphere 55(3):431442. https://doi.org/10.1016/j.chemosphere.2003.10.047

100. Chowdhury A, Maiti SK (2016) Identification of metal tolerant plant species in mangrove ecosystem by using community study and multivariate analysis: a case study from Indian Sunderban. Environ Earth Sci 75:9. https://doi.org/10.1007/s12665-016-5391-1

\section{Publisher's Note}

Springer Nature remains neutral with regard to jurisdictional claims in published maps and institutional affiliations. 